\title{
IMPACT OF SB4 TANK 40 DECANT AND ARP/MCU ADDITIONS WITH/WITHOUT ADDED CAUSTIC ON DWPF CPC PERFORMANCE
}

D. C. Koopman

D. R. Best

M. F. Williams

April 2008

Process Science \& Engineering Section Savannah River National Laboratory Aiken, SC 29808
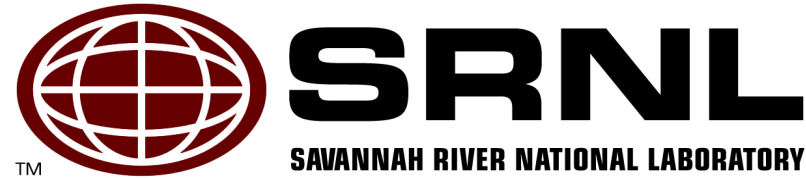


\title{
DISCLAIMER
}

This report was prepared by Washington Savannah River Company (WSRC) for the United States Department of Energy under Contract No. DE-AC09-96SR18500 and is an account of work performed under that contract. Neither the United States Department of Energy, nor WSRC, nor any of their employees makes any warranty, expressed or implied, or assumes any legal liability or responsibility for the accuracy, completeness, or usefulness, of any information, apparatus, or product or process disclosed herein or represents that its use will not infringe privately owned rights. Reference herein to any specific commercial product, process, or service by trademark, name, manufacturer or otherwise does not necessarily constitute or imply endorsement, recommendation, or favoring of same by WSRC or by the United States Government or any agency thereof. The views and opinions of the authors expressed herein do not necessarily state or reflect those of the United States Government or any agency thereof.

\section{Printed in the United States of America}

\author{
Prepared For \\ U.S. Department of Energy
}


WSRC-STI-2008-00147

Revision 0

Key Words: DWPF, SRAT, SME, SB4, ARP, MCU, CPC, Acid, Hydrogen, Rheology, Tank 40

Retention: Permanent

\section{IMPACT OF SB4 TANK 40 DECANT AND ARP/MCU ADDITIONS WITH/WITHOUT ADDED CAUSTIC ON DWPF CPC PERFORMANCE}

D. C. Koopman

D. R. Best

M. F. Williams

April 2008

Process Science \& Engineering Section Savannah River National Laboratory Aiken, SC 29808

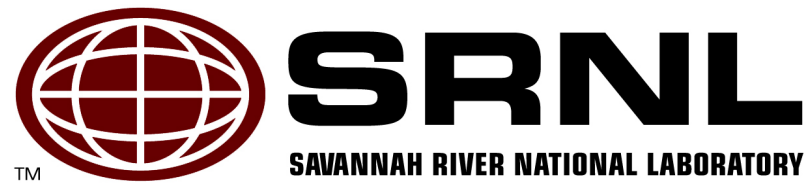




\section{AUTHORS:}

D. C. Koopman, Process Science \& Engineering

Date

D. R. Best, Process Science \& Engineering

Date

M. F. Williams, Process Science \& Engineering

Date

\section{TECHNICAL REVIEWERS:}

M. E. Stone, Process Science \& Engineering

Date

S. H. Reboul, Process Science \& Engineering

Date

\section{APPROVERS:}

J. C. Griffin, Manager, E\&CPT Research Programs

Date

C. C. Herman, Manager, Process Engineering Technology

Date

J. E. Occhipinti, Manager, Process Cognizant Engineering Date Waste Solidification Engineering 


\section{EXECUTIVE SUMMARY}

The Savannah River National Laboratory (SRNL) was requested to investigate the impact of decanting supernate from the Sludge Batch four (SB4) feed in Tank 40. The specific questions concerned the potential impact on the stoichiometric acid window determined for SB4 with respect to overall hydrogen generation rates, nitrite destruction in the Sludge Receipt and Adjustment Tank (SRAT) and the rheology of the sludge, SRAT product, and Slurry Mix Evaporator (SME) product slurries. The scope included considering an addition of sodium hydroxide to Tank 40 to partially offset the sodium lost during decanting as well as considering the impact of bounding quantities of Actinide Removal Process (ARP) feed and Modular Caustic-Side Solvent Extraction Unit (MCU) feed on these same parameters.

Simulated SB4 waste was first adjusted to match the dilution that has occurred in Tank 40 during the initial period of SB4 operations in the DWPF. The adjusted simulant was decanted an equivalent of 100,000 gallons relative to 413,740 gallons projected supernate volume. The decanted simulant was divided into two equal parts. One part received an addition of sodium hydroxide to increase the $\mathrm{Na}_{2} \mathrm{O}$ content of the calcined sludge solids by about 3\%. The baseline decanted simulant and caustic adjusted simulant were each tested in three pairs of DWPF process simulations of the SRAT and SME cycles. The simulations were at the nominal SB4 acid stoichiometry of $130 \%$ with and without bounding ARP/MCU additions and at $170 \%$ of acid without ARP/MCU. The $170 \%$ case without ARP/MCU was considered bounding relative to $170 \%$ with ARP/MCU based on calculated acid requirements.

No significant negative impacts on the proposed acid operating window for the SRAT and SME cycles were noted in the simulations. Nitrite was successfully destroyed and mercury reduced in all six SRAT cycles. Hydrogen was produced in all six SRAT and SME cycles, but the levels were below the DWPF SRAT and SME cycle limits in all cases. Relatively insignificant rheological changes were noted other than the previously established thinning from higher acid additions. SRAT and SME processing at $130 \%$ acid stoichiometry with and without ARP/MCU additions were very similar. MCU nitric acid content, however, shifted the normal acid addition prior to boiling toward more formic acid and less nitric acid than without MCU.

SRNL found no technical issues processing the proposed Tank 40 decant (with or without added $\mathrm{NaOH}$ ) from the standpoint of the impact on the DWPF SRAT and SME cycles subject to the inherent uncertainties in modeling the ARP noble metal concentrations. The noble metals in the ARP were set to the same weight percents in the total solids that they were measured at in the SB4 waste, which was considered likely to be bounding on the actual noble metal content of the ARP transfer to DWPF. Assumptions for formate loss and nitrite to nitrate conversion can be left at the current levels. 


\section{TABLE OF CONTENTS}

EXECUTIVE SUMMARY .........................................................................................

LIST OF FIGURES ..........................................................................................

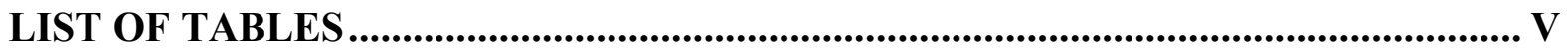

LIST OF ACRONYMS .................................................................................

1.0 INTRODUCTION AND BACKGROUND ........................................................... 1

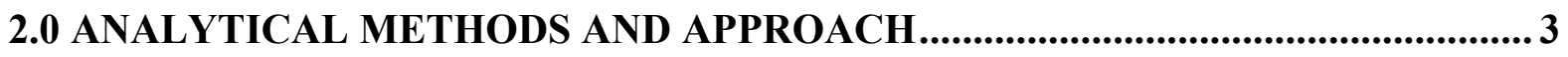

2.1 Process AND SAMPLE ANALYTICAL Methods .................................................... 3

2.2 TANK 40 SIMULANT PREPARATION ...................................................................... 4

2.3 ARP AND MCU SIMULANT PREPARATION ......................................................... 5

2.4 PROCESS SIMULATION ................................................................................ 7

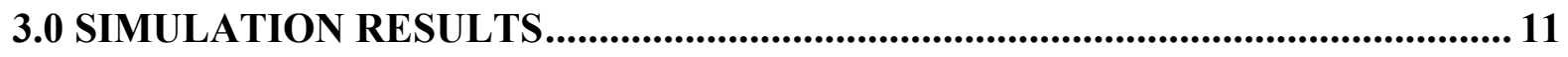

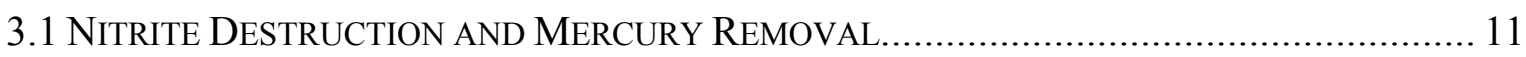

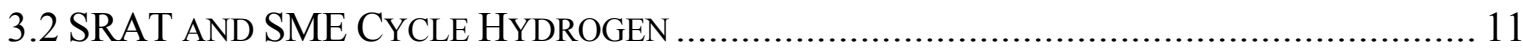

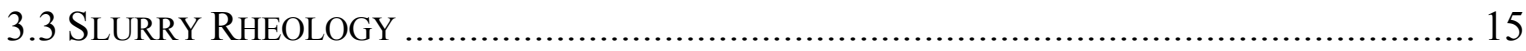

3.4 OTHER SigNIFICANT PROCESSING DATA ............................................................. 16

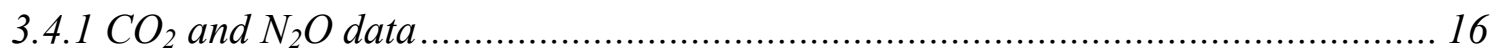

3.4.2 Product anions, anion conversions, and solids data................................... 22

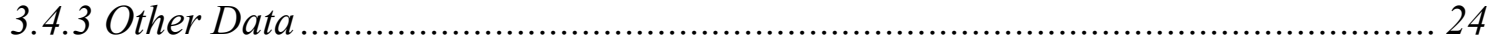

4.0 CONCLUSIONS AND RECOMMENDATIONS.................................................. 27

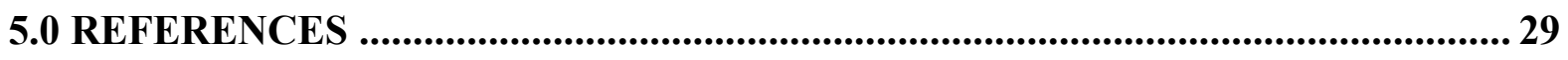

6.0 ACKNOWLEDGEMENTS ......................................................................... 30

APPENDIX A. OTHER SAMPLE DATA........................................................... 31

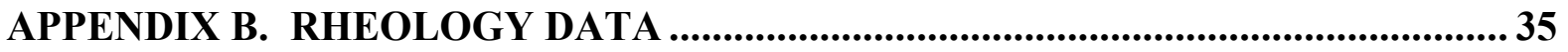




\section{LIST OF FIGURES}

Figure 1. SRAT Cycle Hydrogen at 170\% Stoichiometry ......................................... 12

Figure 2. SME Cycle Hydrogen at 170\% Stoichiometry ............................................. 12

Figure 3. SRAT Cycle Hydrogen at 130\% Stoichiometry (no ARP/MCU) ....................... 13

Figure 4. SME Cycle Hydrogen at 130\% Stoichiometry (no ARP/MCU) .......................... 13

Figure 5. SRAT Cycle Hydrogen at 130\% Stoichiometry (with ARP/MCU) ..................... 14

Figure 6. SME Cycle Hydrogen at 130\% Stoichiometry (with ARP/MCU) ....................... 14

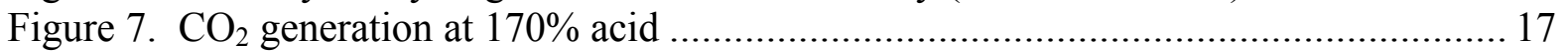

Figure 8. $\mathrm{CO}_{2}$ generation at $130 \%$ acid ................................................................ 17

Figure 9. $\mathrm{CO}_{2}$ generation at $130 \%$ acid with $\mathrm{ARP} / \mathrm{MCU}$........................................... 18

Figure 10. $\mathrm{N}_{2} \mathrm{O}$ generation at $170 \%$ acid ........................................................ 18

Figure 11. $\mathrm{N}_{2} \mathrm{O}$ generation at $130 \%$ acid ................................................................ 19

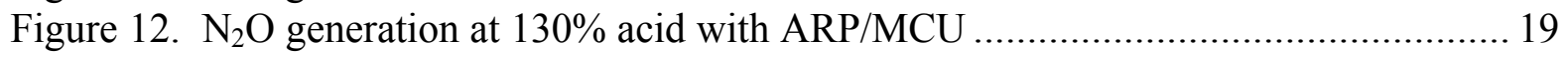

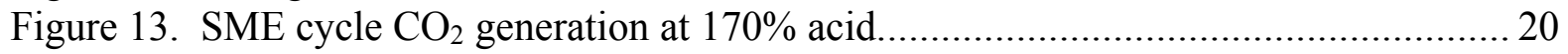

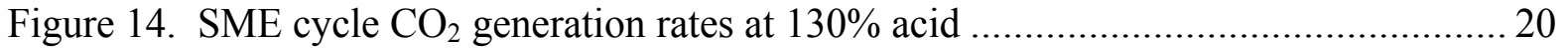

Figure 15. SME cycle $\mathrm{CO}_{2}$ generation rates at $130 \%$ acid with ARP/MCU ...................... 21

Figure 16. Slurry $\mathrm{pH}$ at $130 \%$ stoichiometry ........................................................... 24

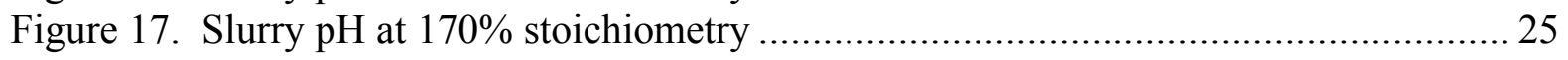

\section{LIST OF TABLES}

Table 1. Elemental Slurry Composition as Calcined Oxides $\left(\mathrm{wt} \%\right.$ at $\left.1100^{\circ} \mathrm{C}\right) \ldots \ldots \ldots \ldots \ldots \ldots . . . . . . . .4$

Table 2. Additional Compositional Measurements ................................................... 5

Table 3. Elemental ARP Slurry Composition ............................................................. 6

Table 4. Additional ARP Compositional Measurements........................................... 7

Table 5. Noble Metals and Mercury, wt $\%$ in Total Solids .......................................... 8

Table 6. Acid Additions for the Various Cases................................................................. 8

Table 7. SRAT Product Mercury Content .................................................................... 11

Table 8. Peak Hydrogen Generation Rates ................................................................ 15

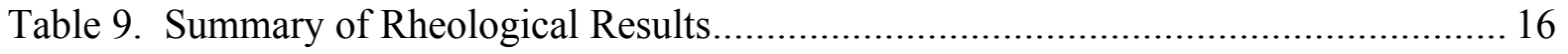

Table 10. Peak Off-gas Generation Rates........................................................... 21

Table 11. Peak Off-gas Concentrations ....................................................................... 21

Table 12. SRAT Product Data................................................................................. 22

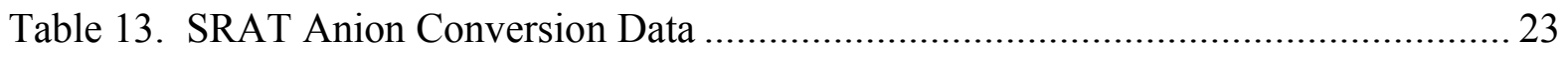

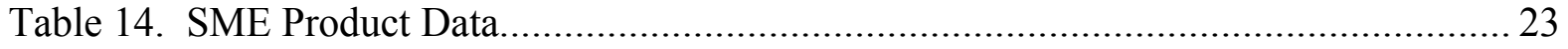

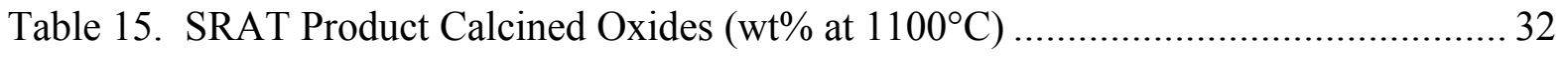

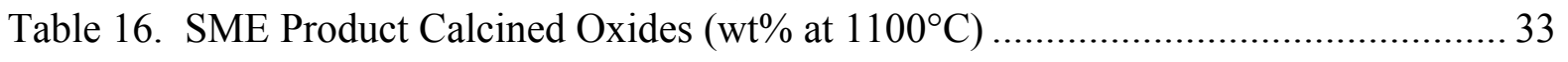




\section{LIST OF ACRONYMS}

$\begin{array}{ll}\text { ACTL } & \text { Aiken County Technology Laboratory } \\ \text { AD } & \text { Analytical Development } \\ \text { ARP } & \text { Actinide Removal Process } \\ \text { CPC } & \text { Chemical Process Cell } \\ \text { DWPF } & \text { Defense Waste Processing Facility } \\ \text { FAVC } & \text { Formic Acid Vent Condenser } \\ \text { GC } & \text { Gas Chromatograph } \\ \text { HM } & \text { H-canyon Modified Purex process } \\ \text { IC } & \text { Ion Chromatography } \\ \text { ICP-AES } & \text { Inductively Coupled Plasma-Atomic Emission Spectroscopy } \\ \text { MCU } & \text { Modular Caustic Side Solvent Extraction Unit } \\ \text { MST } & \text { Mono-Sodium Titanate } \\ \text { MWWT } & \text { Mercury Water Wash Tank } \\ \text { PC } & \text { Personal Computer } \\ \text { PSAL } & \text { Process Science Analytical Laboratory } \\ \text { PSE } & \text { Process Science and Engineering section } \\ \text { ppm } & \text { parts per million } \\ \text { QA } & \text { Quality Assurance } \\ \text { SME } & \text { Slurry Mix Evaporator } \\ \text { SRAT } & \text { Sludge Receipt and Adjustment Tank } \\ \text { SRNL } & \text { Savannah River National Laboratory } \\ \text { TIC } & \text { Total Inorganic Carbon } \\ \text { TT\&QAP } & \text { Task Technical and Quality Assurance Plan } \\ \text { TTR } & \text { Task Technical Request } \\ \text { WSRC } & \text { Washington Savannah River Company } \\ & \end{array}$




\subsection{INTRODUCTION AND BACKGROUND}

Sludge Batch 4 (SB4) is currently being processed in the Defense Waste Processing Facility (DWPF) using Frit 510. The slurry pumps in Tank 40 are experiencing in-leakage of bearing water which is causing the sludge slurry feed (SB4) in Tank 40 to become dilute at a rapid rate. Currently, the DWPF is removing this dilution water by performing caustic boiling during the Sludge Receipt and Adjustment Tank (SRAT) Cycle. In order to alleviate prolonged SRAT cycle times which may eventually impact canister production, decant scenarios of varying amounts of supernate have been proposed for Tank 40. The Savannah River National Laboratory (SRNL) has issued a preliminary assessment evaluating the impacts of three (100, 150, and 200 kilogallon) decant scenarios ${ }^{1}$ (Stone et al. 2007).

Based on the results of the evaluation, the 100,000 gallon decant scenario provided the largest glass processing window for DWPF with the existing Frit 510. The glass operating window for the 100,000 gallon decant was smaller than the current SB4 baseline due to the reduction of $\mathrm{Na}_{2} \mathrm{O}$ concentration upon decanting. SRNL was also requested to evaluate the addition of $\mathrm{NaOH}$ to improve the operating window for DWPF. The results of that assessment indicated that $\mathrm{NaOH}$ additions would have a positive impact on the operating windows. Adding $3 \mathrm{wt} \% \mathrm{Na}_{2} \mathrm{O}$ to the sludge (on a calcine basis, but added as $\mathrm{NaOH}$, after the 100,000 gallon decant), resulted in projected operating windows that were basically the same as the pre-decant or baseline SB4 windows. Changes to the acid consuming and redox impacting species in the Chemical Processing Cell (CPC) have potential processing impacts that cannot be predicted without supporting experimental tests.

Given the potential compositional shifts in the proposed flowsheet changes (100,000 gallon decant, potential additions of $\mathrm{NaOH}$, and/or the addition of the Actinide Removal Process (ARP) stream) to the SB4 system, DWPF has requested that SRNL perform experimental work to define the acid window for SRAT operation. These requests were in the form of a technical task request (TTR). ${ }^{2}$

SRNL issued a Technical Task and Quality Assurance Plan (TTQAP) in response to the TTR. ${ }^{3}$ The TTQAP covered both CPC impacts on the acid window and rheology as well as the potential glass impacts. This report deals with the potential impacts of the Tank 40 decant on the acid window and CPC slurry rheology. 
WSRC-STI-2008-00147

Revision 0

This page intentionally left blank. 


\subsection{ANALYTICAL METHODS AND APPROACH}

This section covers the details of process and sample analytical methods, the preparation of decanted SB4 simulants with and without added $\mathrm{NaOH}$, the preparation of ARP and MCU simulants, and the details of the DWPF CPC process simulations that were performed.

\subsection{Process and Sample Analytical Methods}

The automated data acquisition system was used to collect electronic data from the six 4-L SRAT/SME simulations on a PC. Data included SRAT temperature, bath temperatures for the cooling water to the SRAT condenser and Formic Acid Vent Condenser (FAVC), $\mathrm{pH}$, mixer speed and torque, air and helium purge flows (He is used as an internal standard and is set to $0.5 \%$ of the nominal SRAT or SME air purge flow), and raw gas chromatograph (GC) data.

Agilent 3000A micro GC's were used on the six runs to monitor the off-gas composition. These GCs have two internal analytical columns. Column-A collects data related to $\mathrm{He}, \mathrm{H}_{2}, \mathrm{O}_{2}, \mathrm{~N}_{2}, \mathrm{NO}$, and $\mathrm{CO}$, while column-B collects data related to $\mathrm{CO}_{2}$ and $\mathrm{N}_{2} \mathrm{O}$. GC's were calibrated with a calibration gas containing 0.499 vol $\% \mathrm{He}, 1.010$ vol $\% \mathrm{H}_{2}, 20.00$ vol $\% \mathrm{O}_{2}, 51.0 \mathrm{vol} \% \mathrm{~N}_{2}, 25.0 \mathrm{vol} \% \mathrm{CO}_{2}$ and $2.50 \mathrm{vol} \%$ $\mathrm{N}_{2} \mathrm{O}$. Air was also used to give a two point calibration for $\mathrm{N}_{2}$. CO and $\mathrm{NO}$ peaks were not calibrated. $\mathrm{NO}$ vol\% data was obtained semi-quantitatively using the historical ratios of $\mathrm{He} / \mathrm{NO}$ area factors for the GC's. No evidence for $\mathrm{CO}$ generation was obtained.

The DWPF-scale gas generation rates were calculated from the (gas vol\%/He vol \%) ratio, known He flow, and the scale factor for the test. He flow was controlled by an MKS mass flow controller. The GC's were checked with calibration gas following the SRAT cycle and following the SME cycle. Small sintered metal filters were placed inline on the small diameter sample line to the GCs during the runs. The GC's held calibration fairly well through each SRAT/SME simulation.

The usual $\mathrm{pH}$ probes were used during the six 4-L runs. The $\mathrm{pH}$ probe protocol called for the probe to be calibrated in $\mathrm{pH} 4$ and 10 buffers and checked against $\mathrm{pH} 7$ buffer prior to the SRAT and then checked in all three buffers following the SME cycle.

Process samples were analyzed by various methods. Slurry and supernate elementals were determined by inductively coupled plasma-atomic emission spectroscopy (ICP-AES) for bulk species at the Process Science Analytical Laboratory (PSAL). Slurry samples were calcined at $1100^{\circ} \mathrm{C}$. Consequently, analytical values for $\mathrm{Cr}, \mathrm{Pb}$, and the noble metals will be low. Slurry anions were determined on weighted dilutions after filtering by Ion Chromatography (IC) at PSAL. Aqueous anions were determined on volumetric dilutions by IC. SRAT and SME product slurry densities were measured at the Aiken County Technology Laboratory (ACTL) using the Anton-Parr density instrument. The total, dissolved, and calcined solids were determined by oven drying known sample masses to $115^{\circ} \mathrm{C}$ or $1100^{\circ} \mathrm{C}$. Soluble and insoluble solids were calculated from the total solids and dissolved solids. (Dissolved solids are the total solids in the supernate phase.)

Six SRAT product samples and six SME product samples were submitted to ACTL for rheology measurements, as well as samples of the two Tank 40 simulants. Sludge and SRAT product simulants were characterized by the Haake RS600 rheometer using the Z41 measuring geometry on a shear rate range of $0-600 / \mathrm{sec}$. The SME products were characterized by the same rheometer using the wider gap $\mathrm{Z} 38$ measuring geometry on a shear rate range of $0-300 / \mathrm{sec}$. The samples were held at $25^{\circ} \mathrm{C}$ during the rheometer measurements. 


\subsection{Tank 40 Simulant Preparation}

An SB4 simulant was already available from earlier melt rate testing. Nineteen $\mathrm{kg}$ of simulant were diluted with $10.92 \mathrm{~kg}$ of de-ionized water to simulate the impact of pump seal in-leakage on the wt. \% insoluble solids content of SB4 slurry. The solids were allowed to settle. Supernate was decanted; 6.585 $\mathrm{kg}$ of supernate was equivalent to decanting 100,000 gallons of supernate from 413,740 gallons of liquid in Tank 40. The resulting simulant was divided into two halves of about $11.5 \mathrm{~kg}$ each. A quantity of $\mathrm{NaOH}$ was added to one half to produce an increase of approximately $3 \%$ in the calcined $\mathrm{Na}_{2} \mathrm{O}$ content of the calcined sludge solids. The average measured $\mathrm{Na}_{2} \mathrm{O}$ gain was $2.4 \%$.

The two new simulants were characterized for wt\% solids, density, base equivalents, total inorganic carbon (TIC) of the slurry, slurry anions by IC, slurry elements by ICP-AES, and supernate elements by ICP-AES. Analytical results are presented in Table 1 and Table 2. Comparable results from the composition projection-based 2006 simulant used for the initial SB4 flowsheet studies are shown for comparison. The 2006 simulant was not identical to the starting simulant used to prepare the decant program simulants, nevertheless it was fairly close. The melt rate simulant used to prepare the decanted simulants was closer to the actual SB4 composition measured on the Tank 40 sample. Compositional data from the actual Tank 40 sample analysis were used to project a Tank 40 composition on a uranium free basis at a $16 \% \mathrm{Na}_{2} \mathrm{O}$ composition for comparison to the simulants.

Table 1. Elemental Slurry Composition as Calcined Oxides $\left(w t \%\right.$ at $\left.1100^{\circ} \mathrm{C}\right)$

\begin{tabular}{|c|c|c|c|c|}
\hline & $\begin{array}{c}2006 \\
\text { SB4 } \\
\text { Simulant }\end{array}$ & $\begin{array}{c}\text { Tank 40 } \\
\text { Sample }(16 \% \\
\text { Na, U-free) }\end{array}$ & $\begin{array}{c}\text { Baseline } \\
\text { Decanted } \\
\text { Simulant }\end{array}$ & $\begin{array}{c}\text { Decanted } \\
\text { Simulant } \\
\text { Plus NaOH }\end{array}$ \\
\hline $\mathrm{Al}_{2} \mathrm{O}_{3}$ & 27.4 & 28.2 & 29.6 & 28.5 \\
\hline $\mathrm{BaO}$ & 0.18 & 0.08 & 0.06 & 0.06 \\
\hline $\mathrm{CaO}$ & 2.8 & 3.1 & 3.5 & 3.4 \\
\hline $\mathrm{Cr}_{2} \mathrm{O}_{3}$ & 0.21 & 0.18 & 0.14 & 0.15 \\
\hline $\mathrm{CuO}$ & 0.08 & 0.06 & 0.06 & 0.06 \\
\hline $\mathrm{Fe}_{2} \mathrm{O}_{3}$ & 28.5 & 32.1 & 32.4 & 30.9 \\
\hline $\mathrm{K}_{2} \mathrm{O}$ & 0.36 & $<0.32$ & 0.13 & 0.15 \\
\hline $\mathrm{La}_{2} \mathrm{O}_{3}$ & 0.06 & 0.06 & 0.03 & 0.04 \\
\hline $\mathrm{MgO}_{\mathrm{MnO}}$ & 2.7 & 3.0 & 3.1 & 3.0 \\
\hline $\mathrm{Na}_{2} \mathrm{O}$ & 7.2 & 7.9 & 8.2 & 7.8 \\
\hline $\mathrm{NiO}$ & 20.4 & 16.0 & 15.0 & 1.7 \\
\hline $\mathrm{P}_{2} \mathrm{O}_{5}$ & 1.8 & 1.78 & 1.77 & 0.04 \\
\hline $\mathrm{PbO}^{\mathrm{SO} O}$ & 0.07 & 1.1 & 0.03 & $<0.03$ \\
\hline $\mathrm{SiO}_{2}$ & $<0.02$ & 0.07 & $<0.03$ & 0.71 \\
\hline $\mathrm{TiO}_{2}$ & 1.1 & $1.5^{\dagger}$ & 0.71 & 2.99 \\
\hline $\mathrm{ZnO}_{\mathrm{ZnO}}$ & 4.60 & 3.01 & 3.21 & 0.03 \\
\hline $\mathrm{ZrO}_{2}$ & 0.05 & 0.04 & 0.03 & 0.06 \\
\hline$-\mathrm{nO}_{2}$ & 0.21 & $<0.09$ & 0.05 & 0.07 \\
\hline
\end{tabular}

$\dagger$ - no adjustment for potential sulfate removal during decanting.

The expected outcome was that the decanted simulant plus caustic results would generally have similar, but slightly smaller, values for all of the oxides except sodium, than the 2006 simulant. This general trend was observed, particularly for the major species. The most significant mismatch to the target 
composition based on the Tank 40 sample was for sulfur (sulfate), which was about half that in the Tank 40 sample. No adjustment was made, however, to the Tank 40 sulfur result for decanting soluble sulfate with the sodium.

Table 2. Additional Compositional Measurements

\begin{tabular}{|l|c|c|}
\hline Property & $\begin{array}{c}\text { Baseline } \\
\text { Decanted } \\
\text { Simulant }\end{array}$ & $\begin{array}{c}\text { Decanted } \\
\text { Simulant } \\
\text { Plus NaOH }\end{array}$ \\
\hline Wt\% total solids & 15.0 & 15.2 \\
\hline Wt\% insoluble solids & 11.8 & 11.5 \\
\hline Wt\% soluble solids & 3.2 & 3.8 \\
\hline Wt\% supernate solids & 3.7 & 4.3 \\
\hline Wt\% calcined solids & 10.7 & 11.0 \\
\hline Slurry density, g/mL & 1.11 & 1.11 \\
\hline Supernate density, g/mL & 1.03 & 1.03 \\
\hline pH & 12.2 & 12.8 \\
\hline Slurry nitrite, $\mathrm{mg} / \mathrm{kg}$ & 9800 & 9700 \\
\hline Slurry nitrate, $\mathrm{mg} / \mathrm{kg}$ & 6700 & 6700 \\
\hline Slurry sulfate, $\mathrm{mg} . \mathrm{kg}$ & 1000 & 980 \\
\hline Slurry oxalate, $\mathrm{mg} / \mathrm{kg}$ & 360 & 360 \\
\hline Slurry TIC, $\mathrm{mg} / \mathrm{kg}$ & $1370(450)$ & $1650(50)$ \\
\hline Base equivalents, $\mathrm{M}$, at $\mathrm{pH} 7$ & 0.274 & 0.408 \\
\hline Base equivalents, $\mathrm{M}$, at $\mathrm{pH} 5.5$ & 0.332 & 0.468 \\
\hline
\end{tabular}

Numbers in parentheses are standard deviations for triplicate TIC measurements. $\mathrm{F}^{-}, \mathrm{Cl}^{-}, \mathrm{PO}_{4}{ }^{3-}$, and $\mathrm{HCO}_{2}^{-}$were below the $\mathrm{IC}$ detection limit of $100 \mathrm{mg} / \mathrm{kg}$.

The wt $\%$ insoluble solids target was $11.25 \%$ based on the 1/7/08 Gillam spreadsheet for the baseline case. Projected nitrite, nitrate, and sulfate spreadsheet molarities calculated to approximately 9300 , 5600 , and $1000 \mathrm{mg} / \mathrm{kg}$ slurry respectively.

The difference in the two simulant $\mathrm{pH} 7$ base equivalents was equal to that predicted for the mass of $\mathrm{NaOH}$ added to one half of the decanted slurry. Triplicate measurements of TIC in the baseline decanted simulant samples failed to produce a consistent result. One of the three values was very close to the three TIC results from the decanted simulant with added caustic. A reasonable value of $1600 \mathrm{mg} / \mathrm{kg}$ was selected for the TIC input to the stoichiometric acid calculation in both systems based on a review of the available analytical data (the addition of $\mathrm{NaOH}$ would have produced a negligible dilution of TIC in the half of the simulant with added caustic).

\subsection{ARP and MCU Simulant Preparation}

Simulants were needed for the ARP and MCU streams in addition to the decanted SB4 simulants. Since the organics in MCU have been studied previously and found to be of little consequence to nitrite destruction, hydrogen generation, rheology, etc., the MCU simulant was prepared solely for its potential impact on available acid. ${ }^{4}$ Consequently, the MCU simulant was prepared as $0.033 \mathrm{M}$ nitric acid with no organic additions. This choice simplified preparation while capturing the impact on acid and redox through the nitric acid component.

The ARP simulant recipe was more complicated than MCU. In addition to a multi-species supernate, the ARP simulant contains entrained sludge solids and MST solids. An available generic sludge simulant 
being used by the hydrogen generation program was selected to provide the insoluble sludge solids. This sludge is of intermediate composition between HM and Purex canyon derived sludge wastes. Details have been reported elsewhere. ${ }^{5}$ MST was obtained from the ARP Programs section at $28.3 \mathrm{wt} \%$ total solids. Composition targets were taken from X-CLC-S-00113 for stream 100, the ARP to DWPF. ${ }^{6}$

The MST was concentrated to $36 \mathrm{wt} \%$ total solids by centrifuging and removing supernate. The generic sludge simulant was concentrated to $39 \mathrm{wt} \%$ total solids by centrifuging and removing supernate. These two pastes were then combined with ten sodium salts and de-ionized water to produce the ARP simulant.

Table 3. Elemental ARP Slurry Composition

\begin{tabular}{|c|c|}
\hline & $\begin{array}{c}\text { ARP } \\
\text { Simulant, } \mathrm{mg} / \mathrm{kg}\end{array}$ \\
\hline $\mathrm{Al}$ & 1490 \\
\hline $\mathrm{Ba}$ & 26 \\
\hline $\mathrm{Ca}$ & 308 \\
\hline $\mathrm{Cr}$ & 0.3 \\
\hline $\mathrm{Cu}$ & 13 \\
\hline $\mathrm{Fe}$ & 2770 \\
\hline $\mathrm{K}$ & 31 \\
\hline $\mathrm{Mg}$ & 195 \\
\hline $\mathrm{Mn}$ & 498 \\
\hline $\mathrm{Na}$ & 8230 \\
\hline $\mathrm{Ni}$ & 90 \\
\hline $\mathrm{P}$ & $<10$ \\
\hline $\mathrm{Pb}$ & $<0.02$ \\
\hline $\mathrm{S}$ & 300 \\
\hline $\mathrm{Si}$ & 27 \\
\hline $\mathrm{Ti}$ & 4270 \\
\hline $\mathrm{Zn}$ & 27 \\
\hline $\mathrm{Zr}$ & $<10$ \\
\hline
\end{tabular}


Table 4. Additional ARP Compositional Measurements

\begin{tabular}{|l|c|}
\hline & $\begin{array}{c}\text { ARP } \\
\text { Simulant }\end{array}$ \\
\hline $\mathrm{W} t \%$ total solids & 4.43 \\
\hline $\mathrm{W} \mathrm{t} \%$ insoluble solids & 2.15 \\
\hline $\mathrm{W} \%$ soluble solids & 2.28 \\
\hline $\mathrm{W} \mathrm{t} \%$ supernate solids & 2.33 \\
\hline $\mathrm{Wt} \%$ calcined solids & 2.99 \\
\hline Slurry density, $\mathrm{g} / \mathrm{mL}$ & 1.031 \\
\hline Supernate density, g/mL & 1.016 \\
\hline Slurry nitrite, $\mathrm{mg} / \mathrm{kg}$ & 590 \\
\hline Slurry nitrate, $\mathrm{mg} / \mathrm{kg}$ & 6330 \\
\hline Slurry sulfate, $\mathrm{mg} / \mathrm{kg}$ & 810 \\
\hline Slurry oxalate, $\mathrm{mg} / \mathrm{kg}$ & 3900 \\
\hline Slurry TIC, $\mathrm{mg} / \mathrm{kg}$ & 202 \\
\hline Base equivalents, $\mathrm{M}$, at $\mathrm{pH} 7$ & 0.1482 \\
\hline Base equivalents, M, at $\mathrm{pH} 5.5$ & 0.1700 \\
\hline
\end{tabular}

The tank farm density estimate was $1.031 \mathrm{~g} / \mathrm{mL}$ in Appendix J. ${ }^{6}$ The nitrate target was $6480 \mathrm{mg} / \mathrm{kg}$ and the oxalate target was $3890 \mathrm{mg} / \mathrm{kg}$. The nitrite target was $260 \mathrm{mg} / \mathrm{kg}$, however the nitrite in the sludge simulant paste apparently contributed about $300 \mathrm{mg} / \mathrm{kg}$ to the ARP total. The supernate sodium was $7,500 \mathrm{mg} / \mathrm{L}$ in the supernate, or approximately $0.33 \mathrm{M}$ versus the target of $0.35 \mathrm{M}$.

\subsection{Process Simulation}

Simulations of both the DWPF SRAT cycle and DWPF SME cycle were completed for each scenario in order to produce SRAT and SME product slurry samples required for the rheology measurements. The nominal SRAT cycles included antifoam additions, heat-up, nitric and formic acid additions, dewatering, and reflux. The SRAT cycle was modified for runs with ARP/MCU. ARP addition occurred before acid addition. The total ARP added was in the ratio of 7,000 gal ARP/6,000 gal sludge. The 7,000 gallons represented essentially a full tank bounding volume. ARP was fed to the SRAT at a regular rate while the SRAT was undergoing caustic boiling. The average scaled addition rate was equivalent to the DWPF addition rate. The SRAT condensate was collected and removed such that the end result was a slurry at the same $\mathrm{wt} \%$ total solids as the initial sludge.

The total MCU added was in the ratio of 8,000 gal MCU/6,000 gal sludge. MCU was fed to the SRAT at a controlled rate while the SRAT was at boiling during what was formerly the reflux period. Credit was taken for the nitric acid content of the MCU in the acid and redox calculation for the SRAT cycle. The 130\% stoichiometry case with baseline decanted Tank 40 simulant required no nitric acid addition step. This was caused by the low overall acid addition combined with the nitrate content of the MCU and nitrate and nitrite in the ARP, plus an assumed nitrite to nitrate conversion of about $20 \%$. If the tests were repeated, the nitrite to nitrate conversion would be adjusted to about $10 \%$ based on the results. (The melter feed redox predictions were about $0.25 \mathrm{Fe}^{2+} / \Sigma \mathrm{Fe}$ after sample results from the SME product were received. Consequently, the acid addition should have been made with less formic acid and more nitric acid. The ratio actually used, however, was considered bounding for hydrogen generation.) The SRAT product was targeted to $25 \mathrm{wt} \%$ total solids in each test. This target solids loading caused about a one-third mass reduction from the start of the SRAT to the start of the SME. This constrained the sample volumes before the end of the SME cycle related to maintaining an adequate working volume in the equipment while there was power to the heating mantle. 
Noble metals and mercuric oxide were added to each SRAT batch. Noble metals were added before ARP addition, while $\mathrm{HgO}$ was added after ARP concentration (before acid addition). The Tank 40 targets were taken from the recent C. J. Bannochie report. ${ }^{7}$ The new values were slightly different from those used in the 2006 SB4 simulant flowsheet study. ${ }^{8}$ Noble metals and mercury were assumed to be in the insoluble solids, and the concentrations were adjusted accordingly for the Baseline Decant case and Decant $+\mathrm{NaOH}$ case. The targeted concentrations in $\mathrm{wt} \%$ of the total solids are given in Table 5 .

Table 5. Noble Metals and Mercury, wt\% in Total Solids

\begin{tabular}{|l|c|c|c|c|c|}
\hline & $\mathrm{Ag}$ & $\mathrm{Pd}$ & $\mathrm{Rh}$ & $\mathrm{Ru}$ & $\mathrm{Hg}$ \\
\hline $\begin{array}{l}\text { Initial 2006 SB4 } \\
\text { flowsheet study }^{8}\end{array}$ & 0.0112 & 0.0015 & 0.0108 & 0.0493 & 1.0 \\
\hline Tank 40 Sample & & & & & \\
\hline Baseline Decant & 0.00987 & 0.00124 & 0.0084 & 0.0313 & 0.814 \\
\hline Decant $+\mathrm{NaOH}$ & 0.0112 & 0.00141 & 0.00986 & 0.03674 & 0.92 \\
\hline
\end{tabular}

Two stoichiometric factors were evaluated, the nominal DWPF SB4 factor of $130 \%$ and suggested upper limit of $170 \%$. These two acid addition strategies were tested for the nominal SB4 flowsheet case in 2006 along with two intermediate stoichiometries. ${ }^{8}$ The amounts of acid required per liter of nominal SRAT receipt slurry (including the ARP after concentration to the nominal sludge $w t \%$ total solids) are shown in Table 6. The impact of increasing from $130 \%$ to $170 \%$ is also shown for the four feed cases.

Table 6. Acid Additions for the Various Cases

\begin{tabular}{|l|c|c|c|}
\hline & $\begin{array}{c}130 \% \\
\text { moles/L }\end{array}$ & $\begin{array}{c}170 \% \\
\text { moles/L }\end{array}$ & $\begin{array}{c}170 \%-130 \% \\
\text { moles } / \mathrm{L}\end{array}$ \\
\hline Initial SB4 flowsheet study $^{8}$ & 1.385 & 1.811 & 0.426 \\
\hline Baseline Decanted Tank 40 & 1.157 & 1.513 & 0.356 \\
\hline Decanted Tank 40 + NaOH & 1.332 & 1.742 & 0.410 \\
\hline Baseline + ARP & 1.059 & 1.384 & 0.325 \\
\hline Decanted + NaOH + ARP & 1.190 & 1.556 & 0.366 \\
\hline
\end{tabular}

The acid requirement of baseline decanted SB4 Tank 40 simulant was lower than that for the initial SB4 flowsheet simulant. The acid requirement of decanted SB4 simulant with added caustic was nearly the same as the initial flowsheet simulant, but still slightly lower. If mercury and noble metal loadings had been identical, it could have been argued that the initial flowsheet simulant work would be bounding on the two decant cases.

The acid requirement of the concentrated ARP was less than the acid requirement of an equivalent volume of sludge simulant at equal wt $\%$ total solids. Although there was slightly more base content, the predicted acid consumption due to TIC, Mn, nitrite, and $\mathrm{Hg}$ were all lower for concentrated ARP than for sludge, values in Table 4 times about 3.4 due to concentration from $4.43 \mathrm{wt} \%$ to $15-15.2 \mathrm{wt} \%$ total solids. Consequently, the acid additions were reduced in the runs with ARP relative to the runs with no ARP. Although eight simulations could have been performed during this study, the two $170 \%$ stoichiometry tests with ARP/MCU were optional. Table 6 shows that the increase in acid with ARP/MCU in going from $130 \%$ to $170 \%$ was smaller than without ARP/MCU, so the results from the four tests without ARP/MCU had the potential to bound the optional tests at $170 \%$ with ARP/MCU. 
WSRC-STI-2008-00147

Revision 0

Samples of the SRAT and SME products were obtained. SRAT and SME product samples were sent to PSAL for ICP-AES, IC, $\mathrm{pH}$, and $\mathrm{wt} \%$ solids. SRAT product samples were sent to AD for Hg. SRAT and SME product samples were prepared for density and rheology measurements at ACTL. Each run produced about 1.7-1.8 $\mathrm{L}$ of melter feed at about $45 \mathrm{wt} \%$ total solids. The waste loading target was $34 \%$ sludge oxides in the glass. 
WSRC-STI-2008-00147

Revision 0

This page intentionally left blank. 


\subsection{SIMULATION RESULTS}

The TTR and TTQAP indicated that the focus of the simulation results should be on selected processing results. These included the impact of adding caustic and/or adding ARP/MCU on the SRAT product nitrite and mercury concentrations, SRAT and SME hydrogen generation rates, and SRAT and SME slurry rheological properties. The sections below summarize the results of the simulations with respect to these parameters. Other process and sample data are documented in Appendix A.

\subsection{Nitrite Destruction and Mercury Removal}

SRAT cycle samples of the product slurry were taken to check for nitrite destruction and mercury removal during processing. Nitrite ion concentration was below the detection limit of $100 \mathrm{mg} / \mathrm{kg}$ in all six of the SRAT products (and in all six of the SME products). Mercury was trimmed into the starting simulants at about $0.92 \mathrm{wt} \%$ in the total sludge solids. Mercury analysis of the SRAT product slurry was performed by $\mathrm{AD}$ using the $\mathrm{CV} \mathrm{Hg}$ method. Results were reported in micrograms $\mathrm{Hg}$ per gram slurry, Table 7, and then converted to $\mathrm{wt} \% \mathrm{Hg}$ in the SRAT product total solids using the measured $\mathrm{wt} \%$ total solids of the SRAT product slurry.

Table 7. SRAT Product Mercury Content

\begin{tabular}{|r|c|c|}
\hline Feed - Acid Stoichiometry: & $\mu \mathrm{g} \mathrm{Hg} / \mathrm{g}$ slurry & $\mathrm{wt} \% \mathrm{Hg}$ in total solids \\
\hline Baseline Decanted Tank 40-130\% & 96.6 & 0.037 \\
\hline Baseline Decanted Tank 40-170\% & 49.7 & 0.020 \\
\hline Baseline+ARP/MCU $-130 \%$ & 73.3 & 0.030 \\
\hline Decant+NaOH $-130 \%$ & 97.7 & 0.039 \\
\hline Decant+NaOH $-170 \%$ & 27.8 & 0.011 \\
\hline Decant+NaOH+ARP/MCU $-130 \%$ & 77.9 & 0.034 \\
\hline
\end{tabular}

All six SRAT products were well under the $0.45 \mathrm{wt} \% \mathrm{Hg}$ limit at DWPF. The data indicate 95-99\% removal efficiencies for steam stripping of mercury. Shielded Cells SRAT run SC-1 (30/70 blend) ended with $0.068 \mathrm{wt} \% \mathrm{Hg}$ in the SRAT product total solids, and run SC-5 with ARP ended with $0.31 \mathrm{wt} \% \mathrm{Hg}$. SC-1 had a SB4 blend feed generally similar to the Tank 40 simulant in terms of insoluble species. The new simulant data potentially indicate somewhat more efficient mercury removal than was seen in the two most comparable Shielded Cells runs with real waste.

\subsection{SRAT and SME Cycle Hydrogen}

Hydrogen was produced in the SRAT and SME cycles of all six of the simulations. The DWPF-scaled hydrogen generation rates, however, stayed below the DWPF SRAT and SME limits, 0.65 and 0.223 $\mathrm{lbs} / \mathrm{hr}$ respectively, during all of the testing. The most hydrogen was produced in the two runs at $170 \%$ acid. SRAT cycle data are shown in Figure 1 for the two runs without MCU/ARP at 170\% stoichiometry. 
WSRC-STI-2008-00147

Revision 0

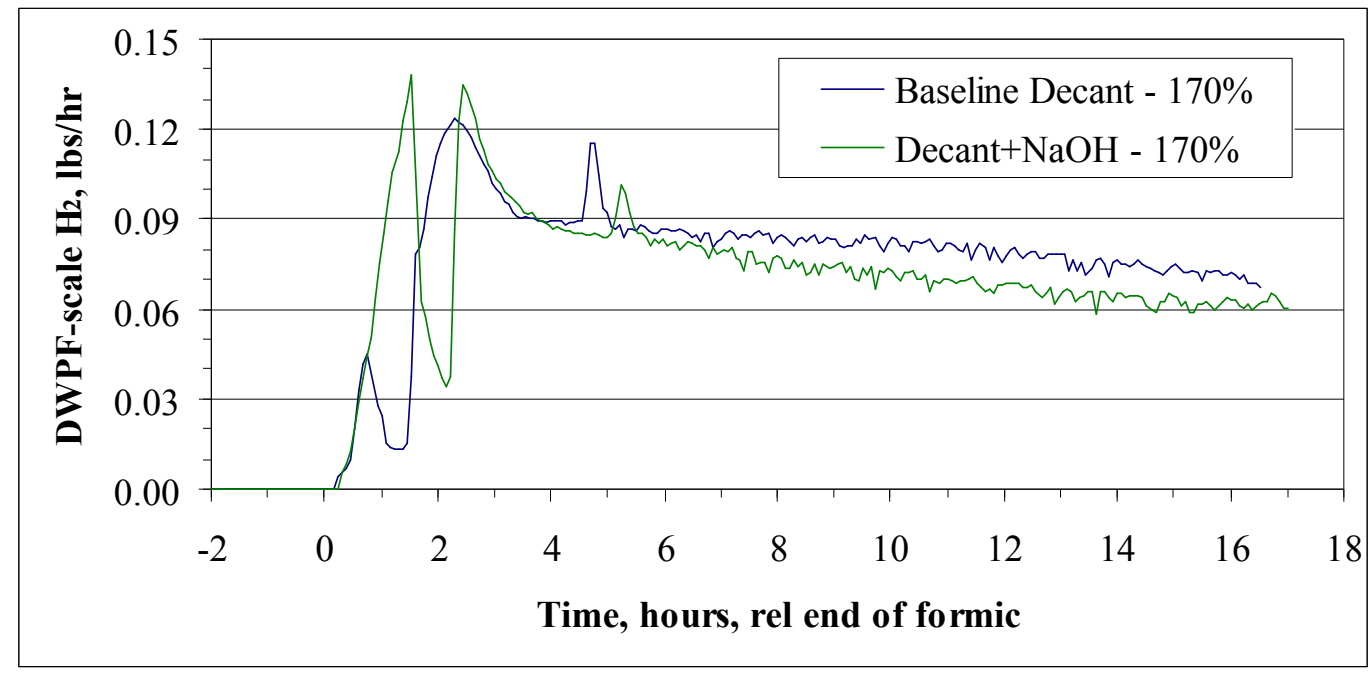

Figure 1. SRAT Cycle Hydrogen at $\mathbf{1 7 0 \%}$ Stoichiometry

The impact of added caustic was to produce a slightly higher peak SRAT generation rate than in the baseline case, although the baseline was producing slightly more hydrogen by the end of the SRAT cycle. The peak rates were less than a quarter of the DWPF SRAT limit. The SME cycle data for these two runs are shown in Figure 2.

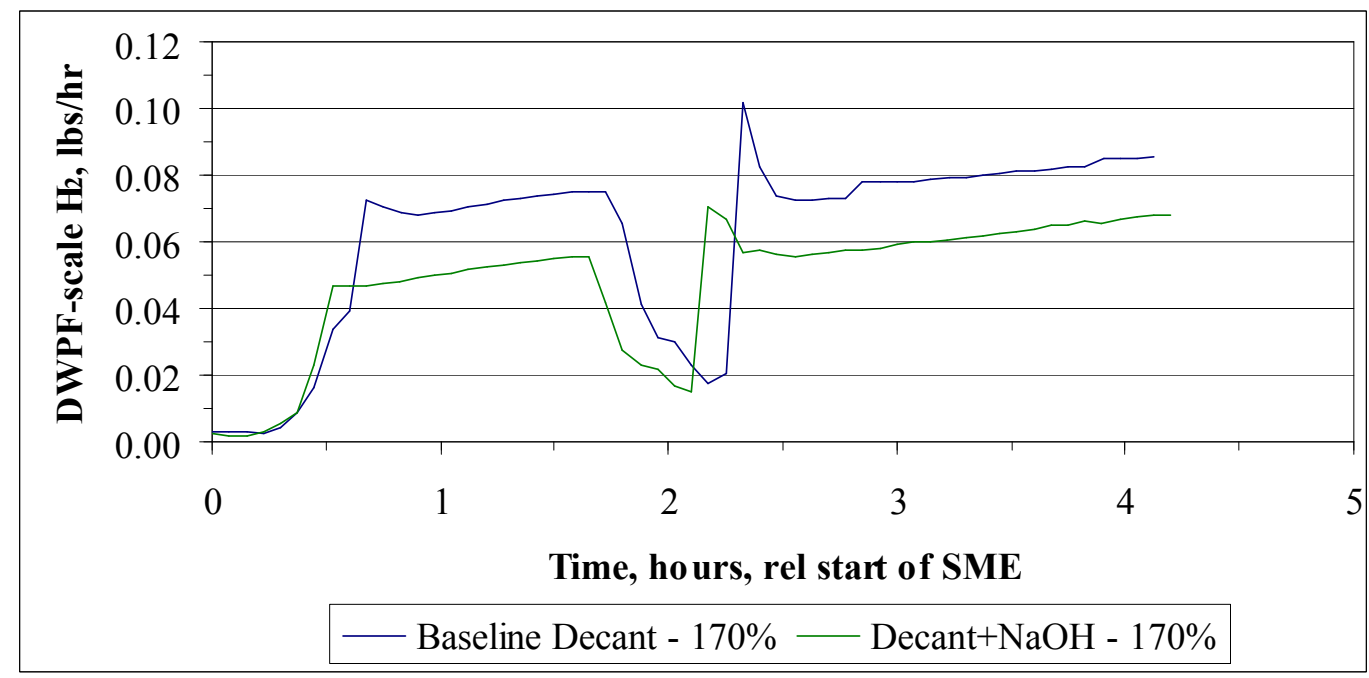

Figure 2. SME Cycle Hydrogen at $170 \%$ Stoichiometry

The trend at the end of the SRAT cycle continued into the beginning of the SME cycle, with the baseline simulant case producing slightly more hydrogen than the simulant with added caustic. The peak rates were $\sim 45 \%$ of the DWPF limit.

The hydrogen generation rate behavior was altered considerably by reducing the acid stoichiometry to $130 \%$. The SRAT cycle hydrogen initiated later, peaked briefly, dipped, and then began a slow rise, Figure 3. 
WSRC-STI-2008-00147

Revision 0

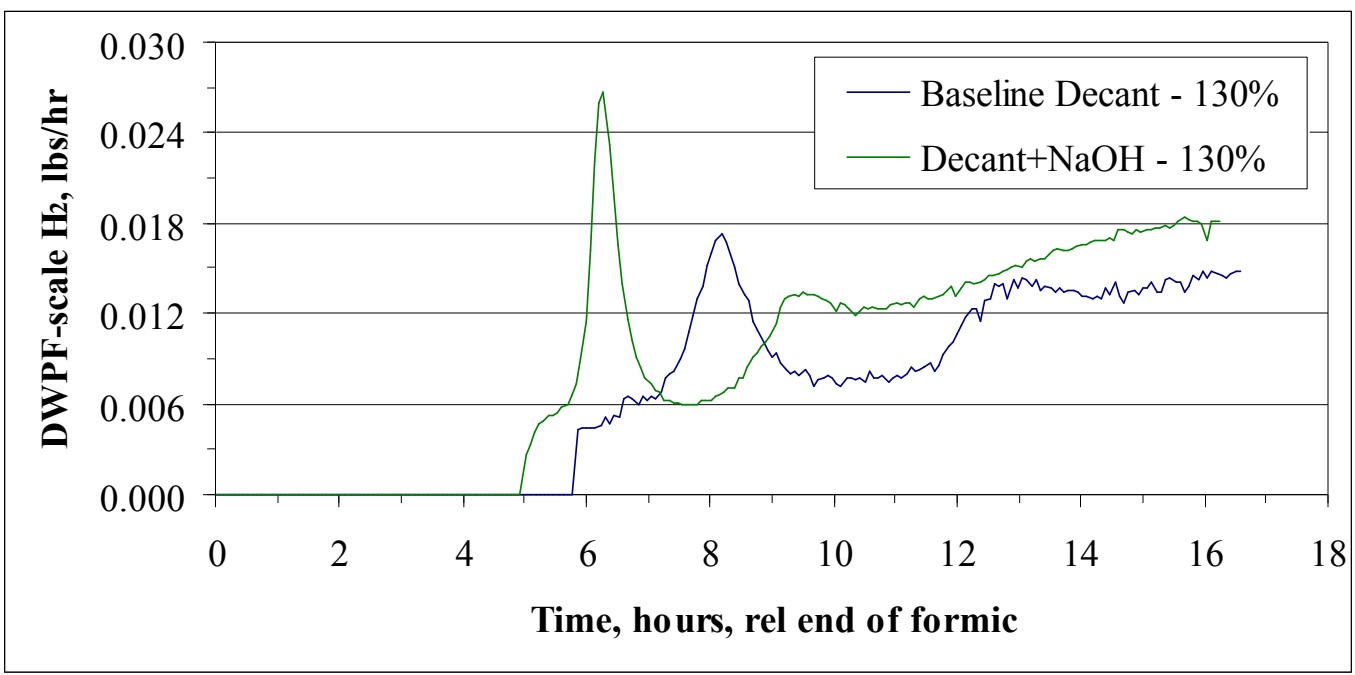

Figure 3. SRAT Cycle Hydrogen at $130 \%$ Stoichiometry (no ARP/MCU)

Once again, the simulant with added caustic (and higher acid addition) produced the larger peak generation rate as expected. Hydrogen initiation was also about an hour earlier in that run, perhaps signaling more rapid nitrite destruction. Hydrogen generation rates were generally $<5 \%$ of the DWPF SRAT limit. The initial SME cycle rates were close to the final SRAT cycle rates, Figure 4.

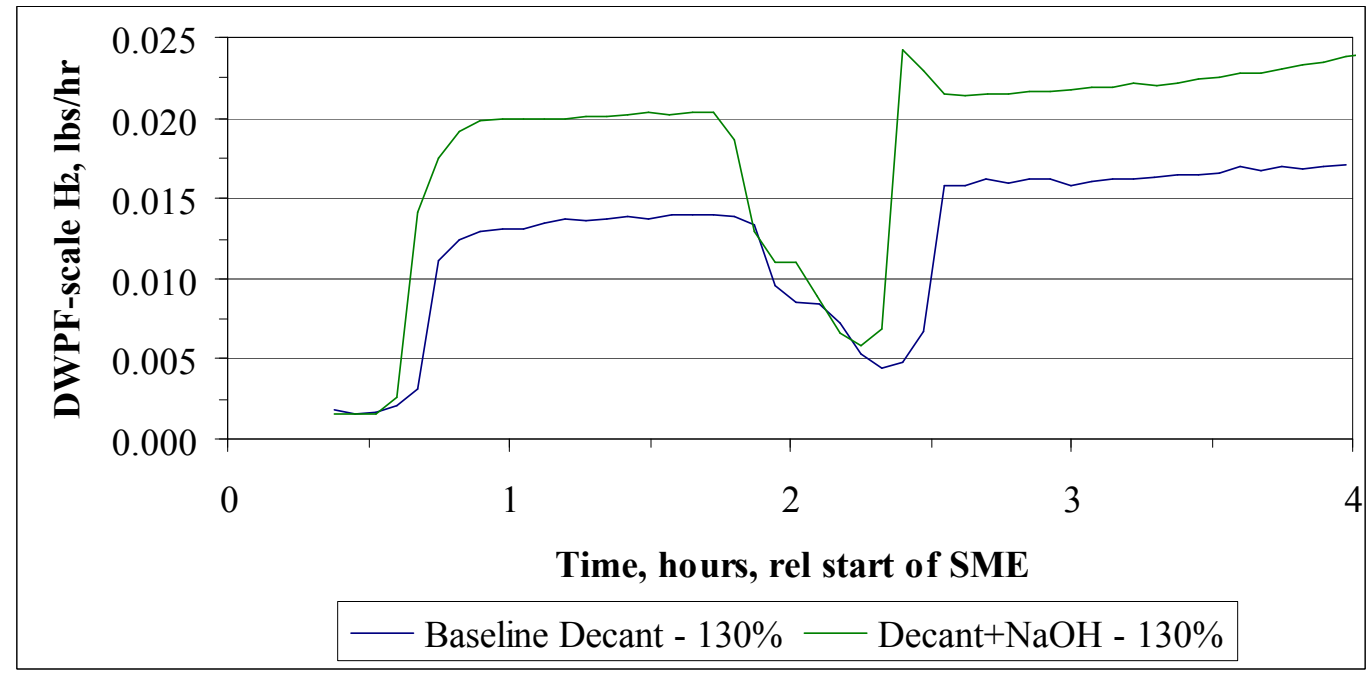

Figure 4. SME Cycle Hydrogen at $130 \%$ Stoichiometry (no ARP/MCU)

The run with added caustic produced more hydrogen than the baseline run throughout the corresponding periods of the SME cycle. Peak generation rates were $<12 \%$ of the DWPF SME limit.

The hydrogen generation rate behavior was altered slightly by adding ARP and MCU at an acid stoichiometry of $130 \%$. The onset of hydrogen generation in the SRAT cycle was still relatively late, Figure 5, as was the case without ARP/MCU at $130 \%$ stoichiometry. 
WSRC-STI-2008-00147

Revision 0

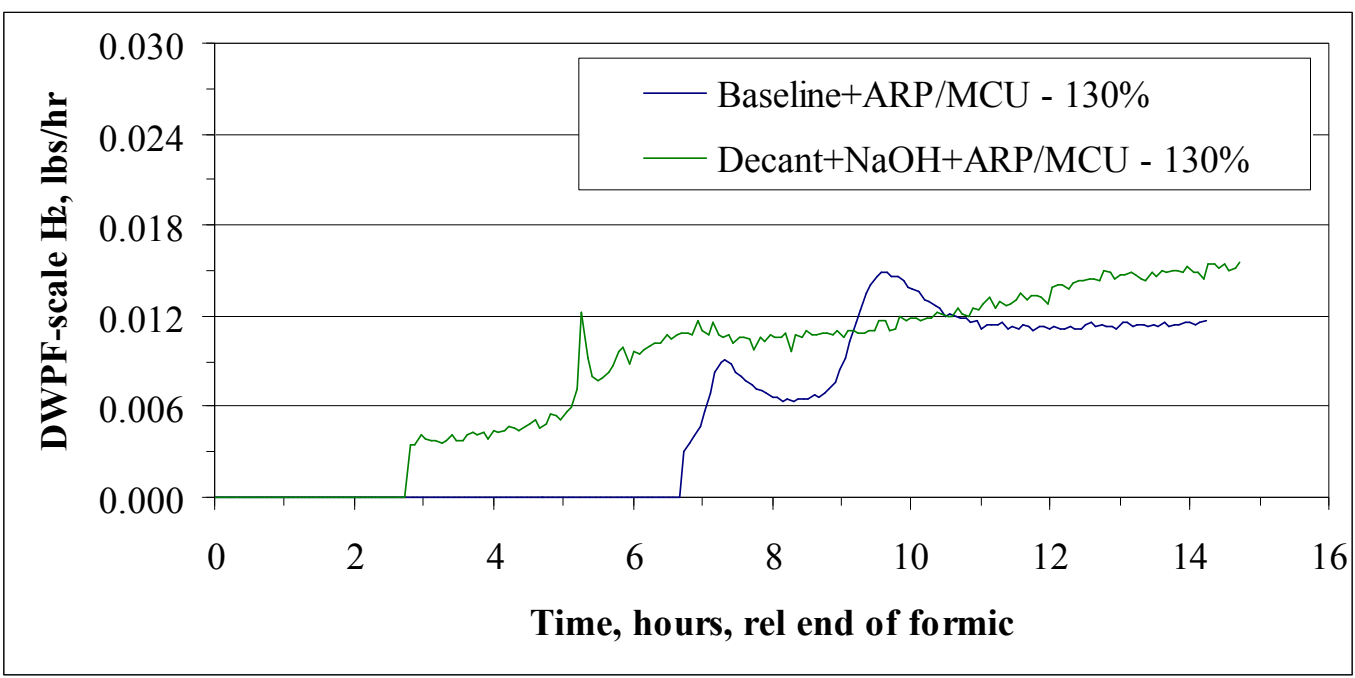

Figure 5. SRAT Cycle Hydrogen at $\mathbf{1 3 0 \%}$ Stoichiometry (with ARP/MCU)

The onset of hydrogen generation occurred sooner with added caustic than with the baseline simulant, but the time difference was larger with ARP/MCU than without. The shifting of a few percent of the acid into the MCU addition, which started about three hours after formic acid addition, in place of reflux probably accounts for most of the differences between Figure 5 and Figure 3, such as the absence of a distinct significant peak early in the hydrogen generation period. SRAT cycle hydrogen generation rates were generally comparable to the two $130 \%$ acid simulations without ARP/MCU. The runs without ARP/MCU appeared to be bounding for the SRAT. The SME cycle data are given in Figure 6.

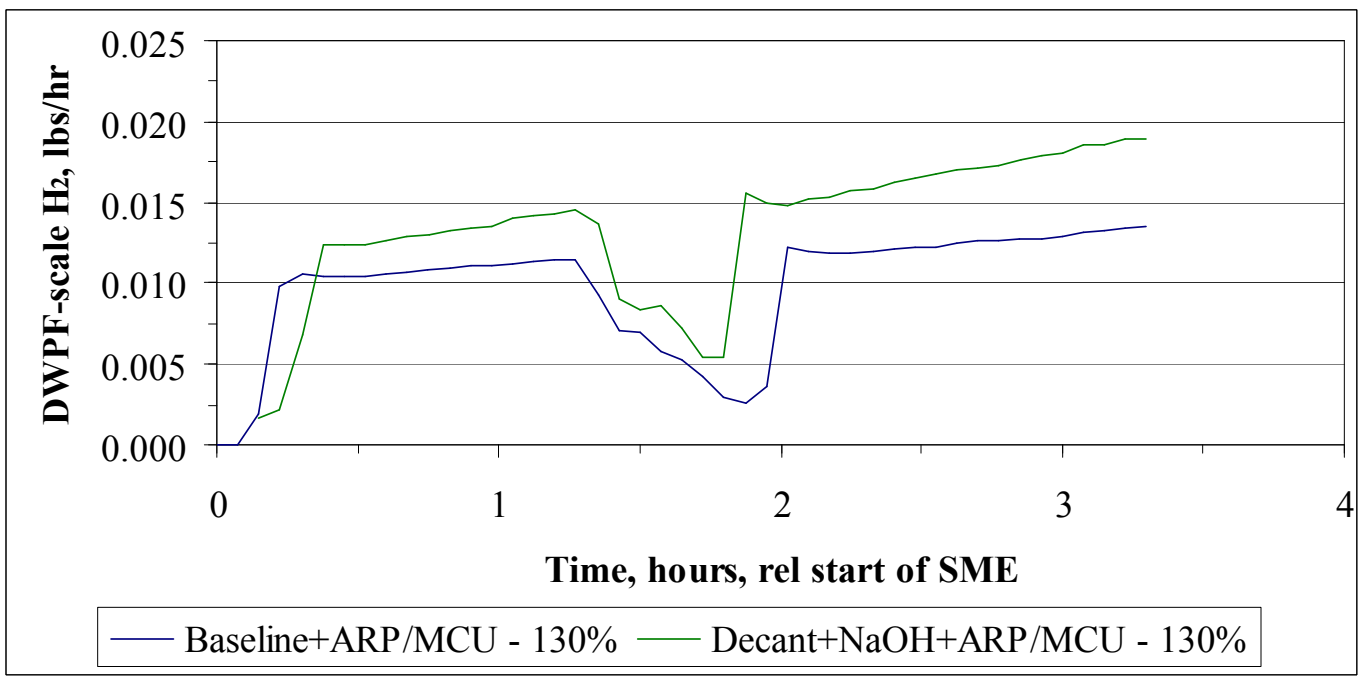

Figure 6. SME Cycle Hydrogen at 130\% Stoichiometry (with ARP/MCU)

The SME cycle hydrogen data with ARP/MCU were similar to, but slightly lower than, the data without ARP/MCU. This was expected, since it appeared from the acid requirements that the ARP/MCU case would be bounded by the non-ARP/MCU case. 
Since the increase in acid required to perform $170 \%$ of stoichiometry tests with ARP/MCU relative to $130 \%$ was smaller than the increase from $130 \%$ to $170 \%$ without ARP/MCU, and since the $130 \%$ test with ARP/MCU made less hydrogen than the $130 \%$ test without ARP/MCU, it was concluded that the $170 \%$ test without ARP/MCU had bounded the hydrogen generation rate behavior of potential tests using $170 \%$ acid with ARP/MCU. Consequently, the decision was made to not perform the two optional process simulations with added ARP/MCU at 170\% stoichiometry.

Peak hydrogen generation rates for the SRAT and SME cycles are summarized in Table 8. The values from the initial 2006 SB4 flowsheet study simulation report are included for comparison.

Table 8. Peak Hydrogen Generation Rates

\begin{tabular}{|c|c|c|}
\hline Feed - Acid Stoichiometry: & $\begin{array}{c}\text { SRAT H } \\
\text { DWPF } 1 \mathrm{bs} / \mathrm{hr}\end{array}$ & $\begin{array}{c}\mathrm{SME} \mathrm{H}_{2}, \\
\text { DWPF lbs/hr }\end{array}$ \\
\hline Initial SB4 Flowsheet Study ${ }^{8}-130 \%$ & 0.045 & 0.009 \\
\hline Initial SB4 Flowsheet Study $^{8}-170 \%$ & 0.117 & 0.121 \\
\hline Baseline Decanted Tank $40-130 \%$ & 0.017 & 0.017 \\
\hline Baseline Decanted Tank $40-170 \%$ & 0.123 & 0.102 \\
\hline Baseline+ARP/MCU $-130 \%$ & 0.015 & 0.013 \\
\hline Decant $+\mathrm{NaOH}-130 \%$ & 0.027 & 0.024 \\
\hline Decant $+\mathrm{NaOH}-170 \%$ & 0.138 & 0.070 \\
\hline Decant+NaOH+ARP/MCU $-130 \%$ & 0.016 & 0.019 \\
\hline
\end{tabular}

The new peak hydrogen generation rate results were generally similar to those in the SB4 flowsheet study, especially at $170 \%$ acid stoichiometry. The four runs at $130 \%$ had slowly increasing hydrogen generation rates toward the end of the SRAT. If the SRAT cycle had been extended, peak generation rates larger than those in Table 8 might have been obtained. There was somewhat less inhibiting mercury in the two new decant simulants than in the initial flowsheet study simulant, which may have contributed to some increased hydrogen generation at the peak in the SRAT cycles at $170 \%$ acid. SRAT cycle mercury, however, may have had little impact on SME cycle peak rates due to the stripping out of mercury during the SRAT cycle and the increasing significance of Ru catalyzed hydrogen generation relative to $\mathrm{Rh}$ catalyzed hydrogen as processing time increases ( $\mathrm{Ru}$ appears to be only weakly inhibited by $\mathrm{Hg})$.

\subsection{Slurry Rheology}

Rheology measurements were made on decanted Tank 40 simulant (baseline) and the decanted simulant with added caustic, as well as on the individual SRAT and SME product slurries as described in Section 2.1. The general process involved making duplicate flow curve measurements and fitting the nearly linear region to the Bingham plastic rheological model. Some samples lacked the linear region in one or both flow curves. In some instances, making a third flow curve measurement improved the overall situation, while in others the Bingham plastic parameters make only a mediocre fit to the data.

The shear stress data for the period where shear rate is ramped up from zero to the maximum differed from the data for the period where shear rate was ramped down from the maximum to zero. In some SME sample cases, it appeared that frit may have been segregated in the rheometer during the up ramp resulting in non-representative down ramp data. Consequently, up ramp yield stress and consistency are reported in Table 9, while the down ramp data were set aside. Raw up curve data from the Haake RS600 rheometer is included as Appendix B. Table 9 also includes SRAT and SME product rheology data for the initial SB4 simulant flowsheet runs at $130 \%$ and $170 \%$ acid stoichiometry for comparison. ${ }^{8}$ 
Table 9. Summary of Rheological Results

\begin{tabular}{|c|c|c|c|c|}
\hline & $\begin{array}{c}\text { Total } \\
\text { Solids } \\
\mathrm{Wt} \% \\
\end{array}$ & $\begin{array}{c}\text { Insoluble } \\
\text { solids } \\
\mathrm{Wt} \%\end{array}$ & $\begin{array}{l}\text { Yield Stress } \\
\text { (Up ramp) } \\
\text { dynes } / \mathrm{cm}^{2}\end{array}$ & $\begin{array}{c}\text { Consistency } \\
\text { (Up ramp) } \\
\text { cP }\end{array}$ \\
\hline \multicolumn{5}{|l|}{ Sludges: } \\
\hline Tank 40 Baseline Decant & 15.0 & 11.8 & 8.0 & 4.0 \\
\hline Tank 40 Baseline Decant+NaOH & 15.2 & 11.5 & 8.4 & 4.1 \\
\hline \multicolumn{5}{|l|}{ SRAT Products: } \\
\hline Initial SB4 Flowsheet Study $^{8}-130 \%$ & 26.4 & 15.4 & 110 & 8.4 \\
\hline Initial SB4 Flowsheet Study $^{8}-170 \%$ & 26.2 & 13.6 & 7.1 & 7.5 \\
\hline Baseline Decanted Tank $40-130 \%$ & 26.2 & 16.9 & 29 & 23 \\
\hline Baseline Decanted Tank $40-170 \%$ & 24.4 & 14.1 & 7.8 & 8.2 \\
\hline Baseline+ARP/MCU $-130 \%$ & 24.1 & 13.7 & 22 & 17 \\
\hline Decant $+\mathrm{NaOH}-130 \%$ & 25.1 & 14.7 & 31 & 17 \\
\hline Decant $+\mathrm{NaOH}-170 \%$ & 25.4 & 15.2 & 4.8 & 6.9 \\
\hline Decant $+\mathrm{NaOH}+\mathrm{ARP} / \mathrm{MCU}-130 \%^{\mathrm{a}}$ & 23.2 & 12.1 & 10 & - \\
\hline \multicolumn{5}{|l|}{ SME Products: } \\
\hline Initial SB4 Flowsheet Study $^{8}-130 \%$ & 46.6 & 37.3 & 157 & 22 \\
\hline Initial SB4 Flowsheet Study $^{8}-170 \%$ & 47.1 & 36.0 & 31 & 13 \\
\hline Baseline Decanted Tank $40-130 \%$ & 46.6 & 38.7 & 150 & 36 \\
\hline Baseline Decanted Tank $40-170 \%$ & 45.3 & 37.0 & 46 & 23 \\
\hline Baseline+ARP/MCU $-130 \%{ }^{\mathrm{a}}$ & 45.3 & 36.6 & 35 & - \\
\hline Decant $+\mathrm{NaOH}-130 \%^{\mathrm{a}}$ & 46.1 & 37.3 & $\sim 60$ & - \\
\hline Decant $+\mathrm{NaOH}-170 \%$ & 45.5 & 37.0 & 30 & 20 \\
\hline Decant $+\mathrm{NaOH}+\mathrm{ARP} / \mathrm{MCU}-130 \%$ & 44.2 & 34.7 & 24 & 16 \\
\hline
\end{tabular}

a - The up curves for this sample were not remotely Bingham plastic shaped. Yield stress was taken visually from the raw flow curve data. Consistency was not estimated.

One of the most obvious impacts was that of increased acid stoichiometry on yield stress. A significant reduction in both SRAT and SME product yield stress was seen by increasing the acid stoichiometry. The SRAT and SME product, made from the baseline decanted simulant were rheologically comparable to the original SB4 flowsheet simulant at similar solids loadings. The impact of adding $\mathrm{NaOH}$ to the baseline simulant produced an apparent small net reduction in yield stress at both acid stoichiometries. The impact of ARP/MCU on SRAT and SME product rheology was not apparent at 130\% stoichiometry, since the four comparable pairs had the slurries including ARP/MCU at lower total and insoluble solids content than the matching slurries without ARP/MCU. Consequently, the lower yield stress was as likely due to dilution as to some factor related to the ARP/MCU addition.

\subsection{Other Significant Processing Data}

This section presents some of the other data obtained during the six process simulations including GC data for species other than hydrogen, $\mathrm{pH}$, and product IC anion results. The remainder of the sample data is included in Appendix A, and the raw rheograms are given in Appendix B.

\subsection{1 $\mathrm{CO}_{2}$ and $\mathrm{N}_{2} \mathrm{O}$ data}

SRAT cycle off-gas data for $\mathrm{CO}_{2}$ and $\mathrm{N}_{2} \mathrm{O}$ are presented below. The first three graphs give SRAT $\mathrm{CO}_{2}$ generation rates at DWPF scale for the three pairs of runs. 
WSRC-STI-2008-00147

Revision 0

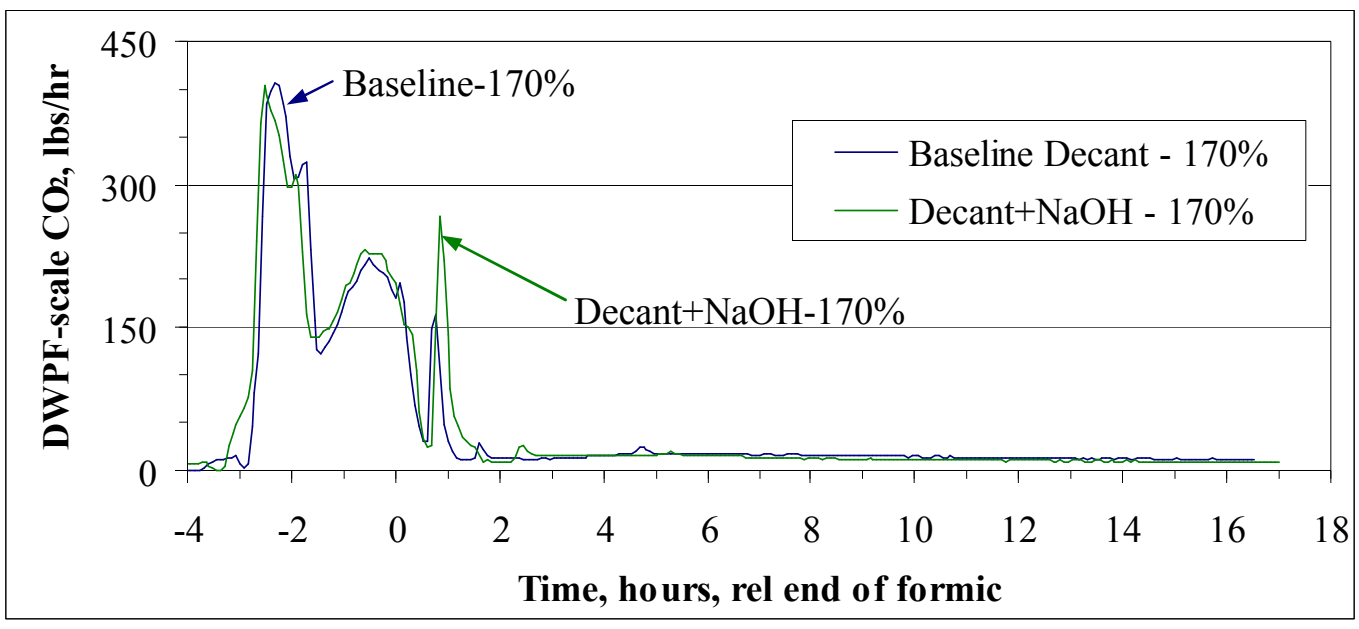

Figure 7. $\mathrm{CO}_{2}$ generation at $170 \%$ acid

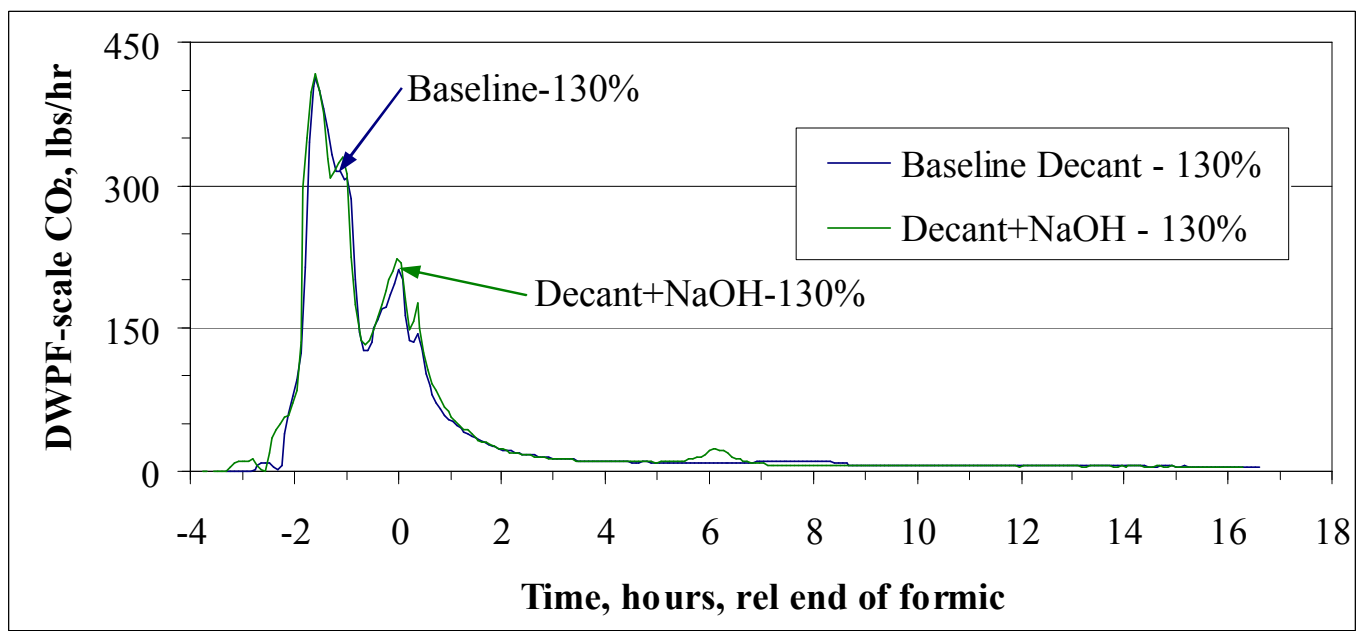

Figure 8. $\mathrm{CO}_{2}$ generation at $130 \%$ acid

The four sets of $\mathrm{CO}_{2}$ data are very similar during acid addition as expected for two feeds with identical TIC, Mn, and nitrite ion contents. Small peaks at about +0.5 hours correspond to the start of boiling. 
WSRC-STI-2008-00147

Revision 0

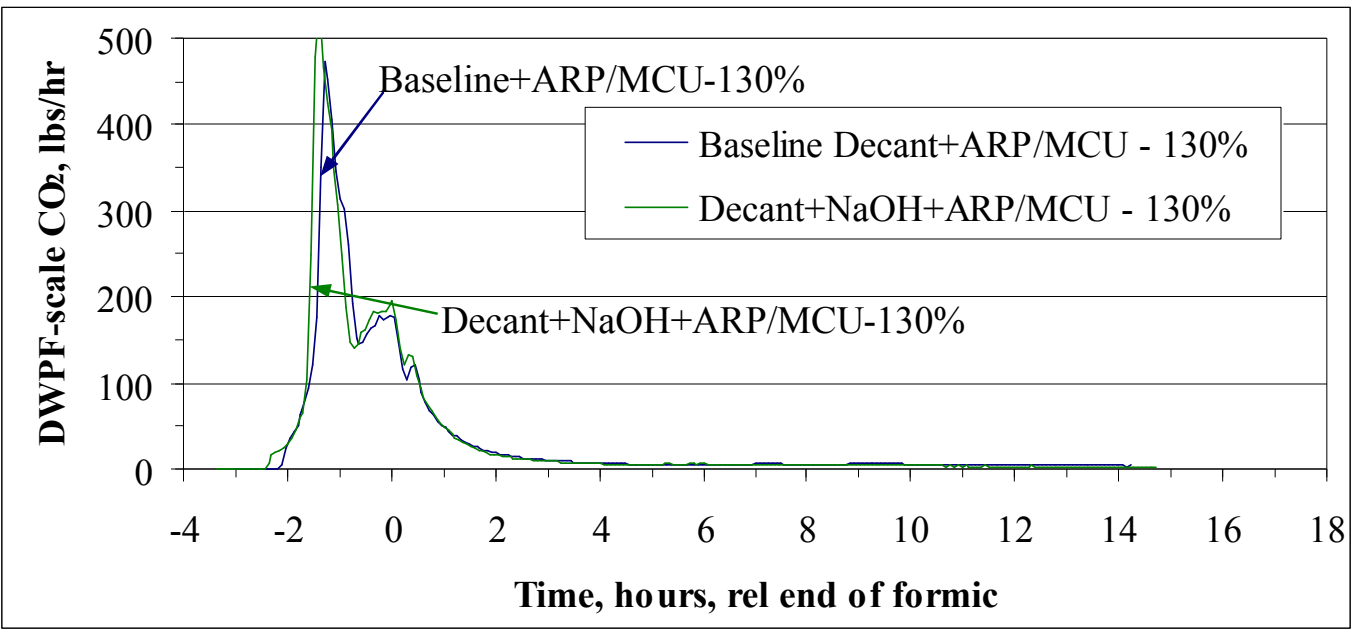

Figure 9. $\mathrm{CO}_{2}$ generation at $130 \%$ acid with ARP/MCU

The presence of additional TIC in the SRAT receipt slurry of the runs with ARP was evident in the higher peak generation rates at about -1.5 hours (TIC destruction peak) compared to the four runs without ARP. ARP simulant had a higher TIC content after it was concentrated to the same solids loading as SB4 simulant. The next three graphs give the SRAT $\mathrm{N}_{2} \mathrm{O}$ generation rates.

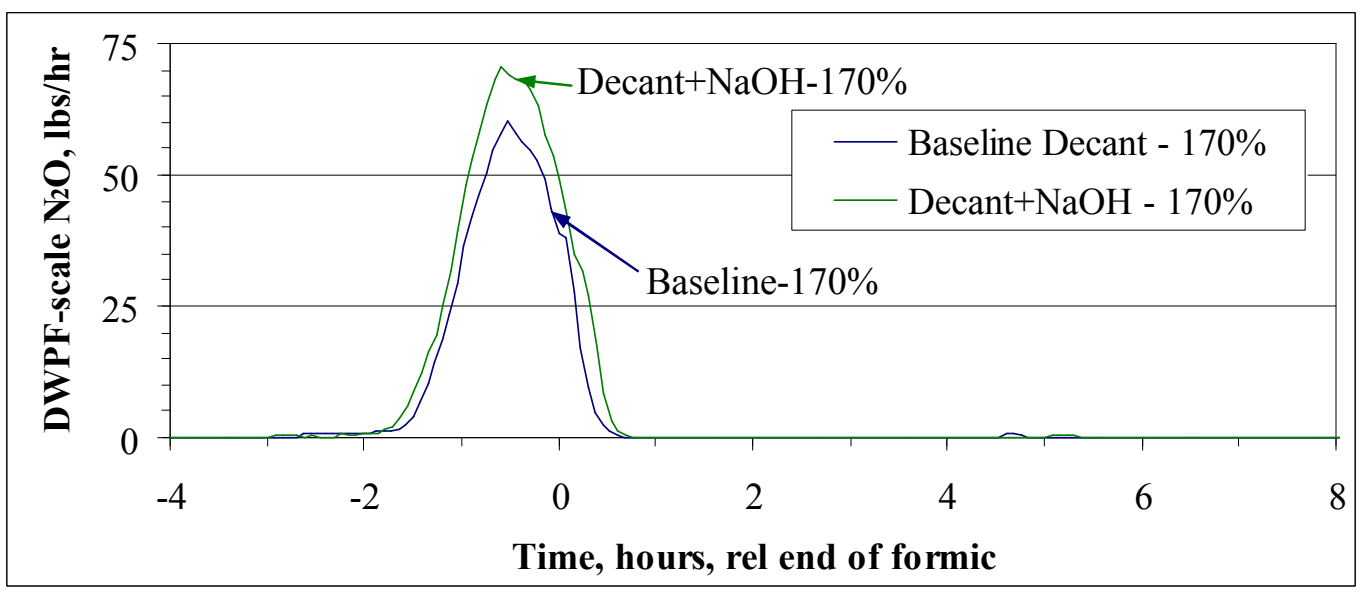

Figure 10. $\mathrm{N}_{2} \mathrm{O}$ generation at $170 \%$ acid 
WSRC-STI-2008-00147

Revision 0

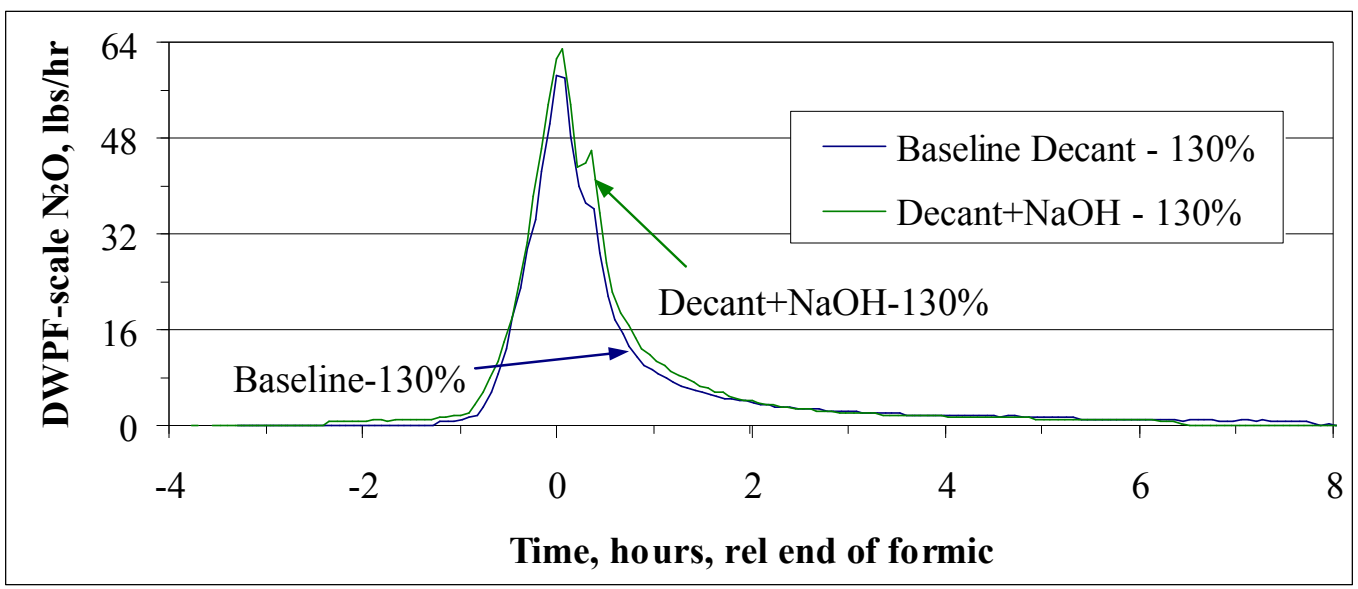

Figure 11. $\mathrm{N}_{2} \mathrm{O}$ generation at $130 \%$ acid

The four sets of $\mathrm{N}_{2} \mathrm{O}$ data without $\mathrm{ARP} / \mathrm{MCU}$ data were all fairly similar. This result was not unexpected given the identical noble metal loadings and initial nitrite ion concentrations.

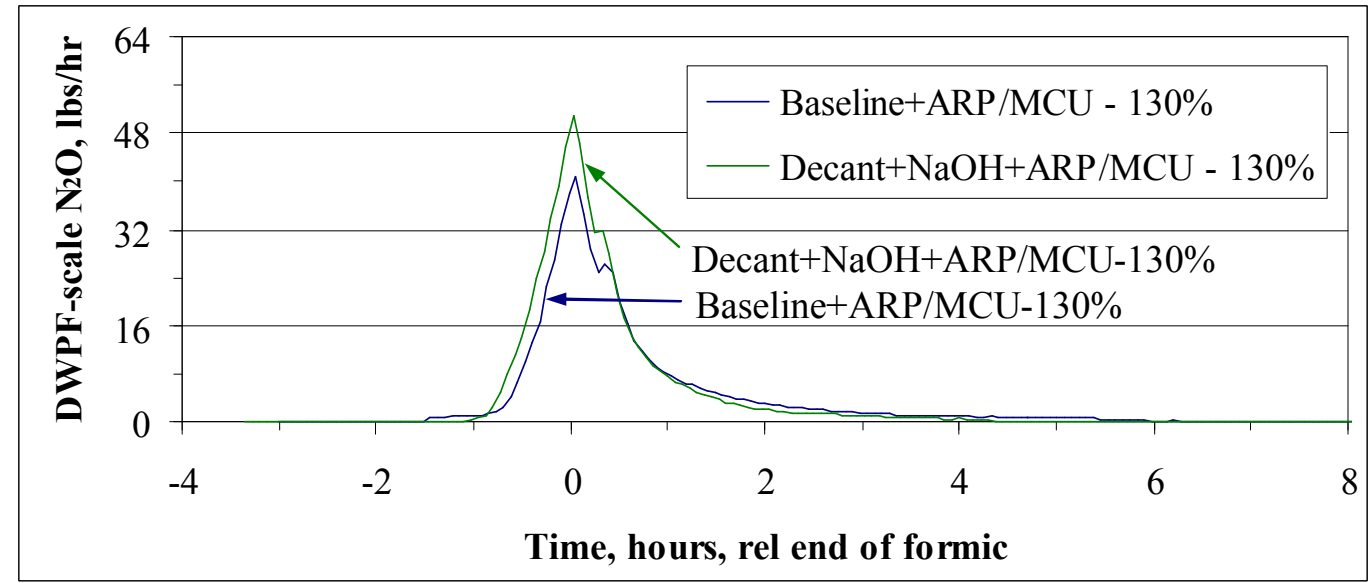

Figure 12. $\mathrm{N}_{2} \mathrm{O}$ generation at $130 \%$ acid with $\mathrm{ARP} / \mathrm{MCU}$

A reduction in both peak and total $\mathrm{N}_{2} \mathrm{O}$ production occurred when ARP was substituted for a portion of the sludge in the SRAT receipt mass. The concentrated ARP/SB4 starting slurry also contained less total nitrite ion than the other cases. MCU had little apparent impact on the evolved oxides of nitrogen, since nitrite ion destruction was essentially complete before MCU addition began. The next three graphs give $\mathrm{SME}$ cycle $\mathrm{CO}_{2}$ generation rates for the three pairs of simulations. 
WSRC-STI-2008-00147

Revision 0

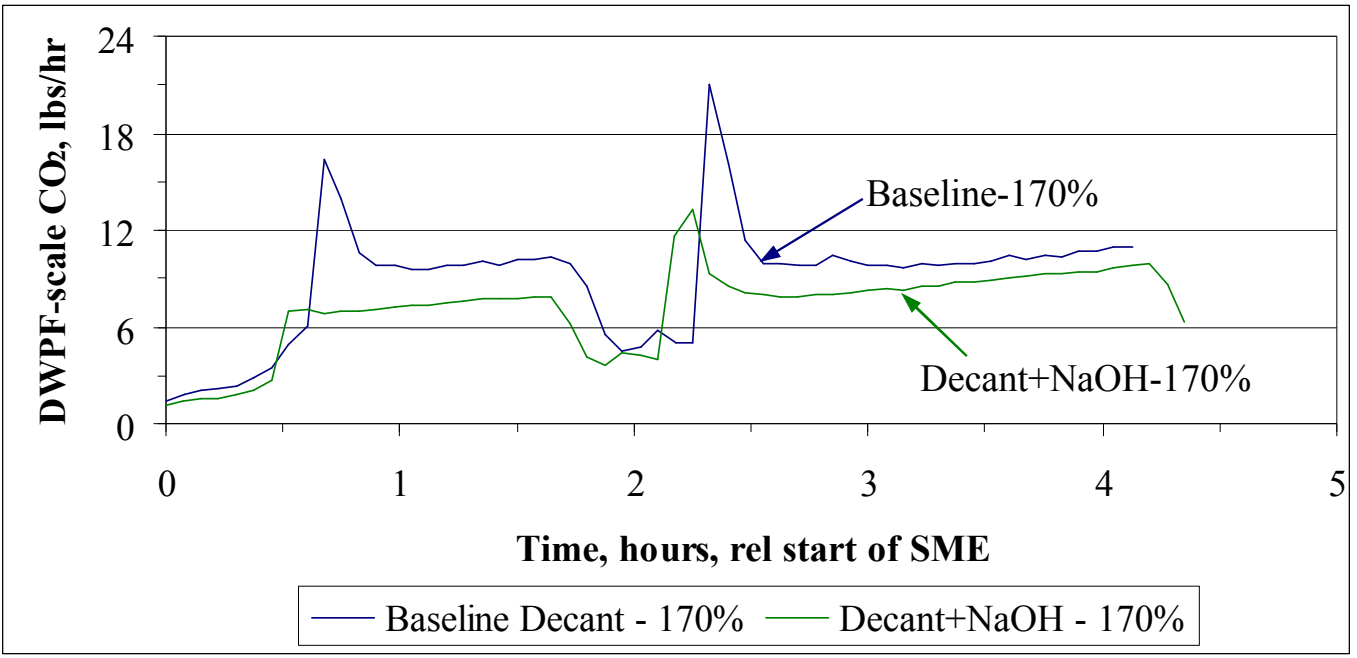

Figure 13. SME cycle $\mathrm{CO}_{2}$ generation at $170 \%$ acid

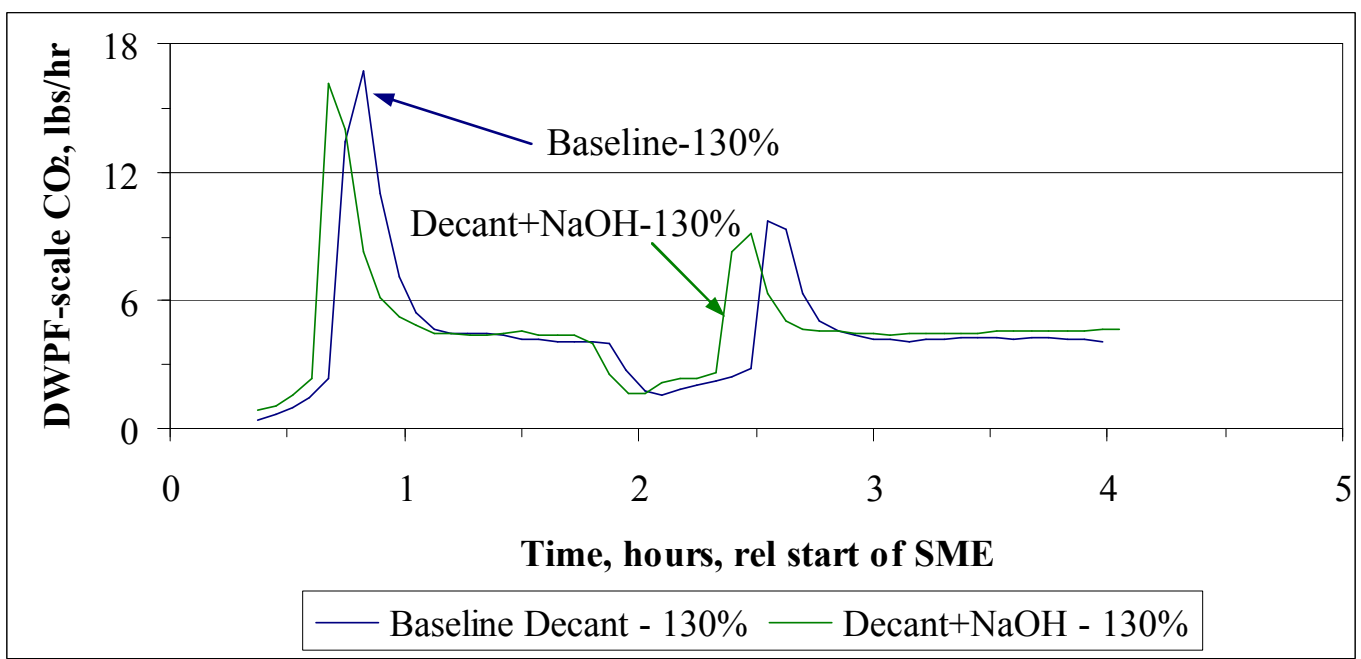

Figure 14. SME cycle $\mathrm{CO}_{2}$ generation rates at $130 \%$ acid 


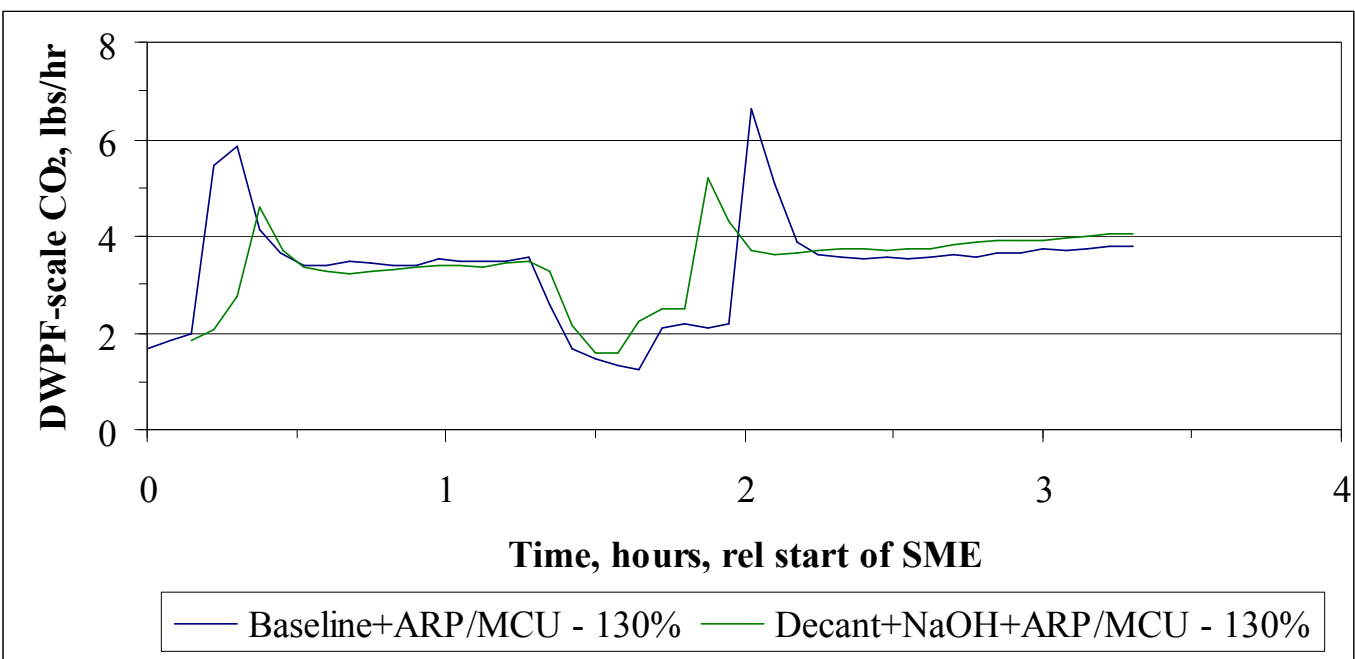

Figure 15. SME cycle $\mathrm{CO}_{2}$ generation rates at $130 \%$ acid with $\mathrm{ARP} / \mathrm{MCU}$

The SME $\mathrm{CO}_{2}$ data did not fall into any obvious patterns. Peak generation rates and maximum measured off-gas concentrations were taken from the processed GC data. These quantities are summarized in Table 10 and Table 11.

Table 10. Peak Off-gas Generation Rates

\begin{tabular}{|r|c|c|c|}
\hline Feed - Acid Stoichiometry: & $\begin{array}{c}\text { SRAT } \mathrm{CO}_{2}, \\
\text { DWPF lbs/hr }\end{array}$ & $\begin{array}{c}\mathrm{SME} \mathrm{CO}_{2}, \\
\text { DWPF lbs/hr }\end{array}$ & $\begin{array}{c}\text { SRAT N } 2 \mathrm{O}, \\
\text { DWPF lbs/hr }\end{array}$ \\
\hline Baseline Decanted Tank 40-130\% & 412 & 16.7 & 58.6 \\
\hline Baseline Decanted Tank 40-170\% & 406 & 21.1 & 60.1 \\
\hline Baseline+ARP/MCU - 130\% & 473 & 6.6 & 40.7 \\
\hline Decant+NaOH - 130\% & 418 & 16.1 & 63.0 \\
\hline Decant+NaOH - 170\% & 405 & 13.3 & 70.5 \\
\hline Decant+NaOH+ARP/MCU - 130\% & 542 & 5.2 & 50.8 \\
\hline
\end{tabular}

Table 11. Peak Off-gas Concentrations

\begin{tabular}{|r|c|c|c|}
\hline Feed - Acid Stoichiometry: & $\begin{array}{c}\mathrm{SRAT} \mathrm{CO}_{2}, \\
\text { Vol. } \%\end{array}$ & $\begin{array}{c}\mathrm{SME} \mathrm{CO}_{2}, \\
\text { Vol. } \%\end{array}$ & $\begin{array}{c}\text { SRAT N } \\
\text { Vol. } \%\end{array}$ \\
\hline Baseline Decanted Tank 40-130\% & 19.4 & 2.8 & 1.2 \\
\hline Baseline Decanted Tank 40-170\% & 19.1 & 3.6 & 0.7 \\
\hline Baseline+ARP/MCU - $130 \%$ & 22.6 & 1.1 & 0.7 \\
\hline Decant+NaOH - 130\% & 19.8 & 2.8 & 0.7 \\
\hline Decant+NaOH - 170\% & 19.2 & 2.3 & 1.2 \\
\hline Decant+NaOH+ARP/MCU - $130 \%$ & 24.2 & 0.9 & 1.2 \\
\hline
\end{tabular}

It appeared that the two major factors affecting the $\mathrm{CO}_{2}$ and $\mathrm{N}_{2} \mathrm{O}$ data were the increased TIC and reduced nitrite in the SRAT receipt slurry prior to acid addition in the pair of runs with ARP/MCU. This was caused by the ARP composition and not by the substitution of MCU addition for reflux. The major period of SRAT off-gas evolution came prior to the start of MCU addition. Some of the variations in the peak SRAT $\mathrm{CO}_{2}$ generation rate and volume percent can be attributed to the 4.5 minute sampling rate of 
the GC. For example, the $130 \%$ run using decanted simulant plus caustic with ARP/MCU had the following five consecutive GC readings during TIC destruction: $12.6 \%, 21.7 \%, 24.2 \%, 21.7 \%$, and $20.0 \%$. When the species concentration is changing this quickly, it is possible to miss the region of the peak in the sampling sequence. The matching baseline simulant run with ARP/MCU had two consecutive readings over $22 \%$, so it would not be proper to conclude that the actual peak generation rate in the test with baseline simulant plus ARP/MCU was lower than in the corresponding run with added caustic. The raw data are not that precise.

\subsubsection{Product anions, anion conversions, and solids data}

The analytical slurry anion concentrations and solids data for the SRAT products are presented below, Table 12. The table also includes the slurry density and $\mathrm{pH}$. The oxalate anion data is from a weighted dilution preparation with water that historically only gives a partial uptake of oxalate into the supernate, so the oxalate concentrations should be viewed as lower bounds.

Table 12. SRAT Product Data

\begin{tabular}{|c|c|c|c|c|c|c|}
\hline & $\begin{array}{c}\text { Baseline } \\
130 \%\end{array}$ & $\begin{array}{c}\text { Baseline } \\
170 \%\end{array}$ & $\begin{array}{c}\text { Baseline }+ \\
\text { ARP/MCU }\end{array}$ & $\begin{array}{c}\mathrm{w} / \mathrm{NaOH} \\
130 \%\end{array}$ & $\begin{array}{c}\mathrm{w} / \mathrm{NaOH} \\
170 \%\end{array}$ & $\begin{array}{c}\mathrm{w} / \mathrm{NaOH}+ \\
\mathrm{ARP} / \mathrm{MCU}\end{array}$ \\
\hline $\mathrm{Wt} \% \mathrm{TS}$ & 26.2 & 24.4 & 24.1 & 25.1 & 25.4 & 23.2 \\
\hline $\mathrm{Wt} \% \mathrm{IS}$ & 17.0 & 14.1 & 13.7 & 14.7 & 15.2 & 12.1 \\
\hline $\mathrm{Wt} \% \mathrm{SS}$ & 9.2 & 10.3 & 10.4 & 10.4 & 10.2 & 11.0 \\
\hline $\mathrm{Wt} \% \mathrm{CS}$ & 17.2 & 14.2 & 15.1 & 16.0 & 15.1 & 14.2 \\
\hline $\mathrm{Density,} \mathrm{g/mL}$ & 1.163 & n.a. & 1.167 & 1.179 & n.a. & 1.166 \\
\hline $\mathrm{pH}$ & 6.97 & 4.77 & 6.17 & 6.75 & 4.63 & 5.63 \\
\hline $\mathrm{HCO}_{2}^{-}, \mathrm{mg} / \mathrm{kg}$ & 53,000 & 56,200 & 54,400 & 58,000 & 65,700 & 58,500 \\
\hline $\mathrm{NO}_{3}^{-}, \mathrm{mg} / \mathrm{kg}$ & 17,000 & 21,200 & 19,200 & 19,500 & 22,200 & 19,500 \\
\hline $\mathrm{NO}_{2}^{-}, \mathrm{mg} / \mathrm{kg}$ & $<100$ & $<100$ & $<100$ & $<100$ & $<100$ & $<100$ \\
\hline $\mathrm{SO}_{4}^{2-}, \mathrm{mg} / \mathrm{kg}$ & 590 & n.a. & 2,120 & 570 & n.a. & 2,070 \\
\hline $\mathrm{C}_{2} \mathrm{O}_{4}^{2-}, \mathrm{mg} / \mathrm{kg}$ & $<100$ & $<100$ & 900 & $<100$ & $<100$ & 880 \\
\hline $\mathrm{Cl}^{-}, \mathrm{mg} / \mathrm{kg}$ & 180 & 170 & 220 & 180 & 150 & 210 \\
\hline
\end{tabular}

n.a. - not analyzed

The two $170 \%$ run SRAT product samples were fairly small. Consequently, a few SRAT product analyses such as density and sulfate were not performed or requested. There was a fairly significant increase in sulfate concentration when ARP was blended into either starting sludge and concentrated.

The three different SRAT products from the simulant with added caustic had lower $\mathrm{pH}$ (more residual acid) than the matching products with baseline simulant. This trend was also seen in the SME product $\mathrm{pH}$ data, and it suggests that the stoichiometric factor could have been dropped in the runs with added caustic relative to the runs with the baseline decanted simulant. This conclusion was supported by the relative hydrogen generation rate data. The suitability of a smaller overall stoichiometric coefficient was consistent with the added $\mathrm{NaOH}$ needing a stoichiometric factor of 1.00 , but it being given the full stoichiometric factor of the bulk simulant slurry (1.30 or 1.70). Fortunately, the additional excess acid added in the three tests with simulant plus caustic was not sufficient to trigger excessive hydrogen generation for the case of the decanted Tank 40 simulant composition (mercury, noble metals, and the stoichiometric acid demand in moles/L sludge).

Nitrite to nitrate conversion and formate loss were calculated for the six SRAT cycles. Nitrite to nitrate conversion gives the percent of the initial nitrite that must be converted into nitrate to explain the nitrate 
in the SRAT product. It does not account for nitrate in the condensate streams removed during processing.

Table 13. SRAT Anion Conversion Data

\begin{tabular}{|c|c|c|c|c|c|c|}
\hline & $\begin{array}{c}\text { Baseline } \\
130 \%\end{array}$ & $\begin{array}{c}\text { Baseline } \\
170 \%\end{array}$ & $\begin{array}{c}\text { Baseline }+ \\
\text { ARP/MCU }\end{array}$ & $\begin{array}{c}\text { w/NaOH } \\
130 \%\end{array}$ & $\begin{array}{c}\text { w/NaOH } \\
170 \%\end{array}$ & $\begin{array}{c}\text { w/NaOH+ } \\
\text { ARP/MCU }\end{array}$ \\
\hline $\begin{array}{c}\text { Nitrite to Nitrate } \\
\text { conversion, \% }\end{array}$ & 8 & 6 & 6 & 5 & 8 & 5 \\
\hline $\begin{array}{c}\text { Formate } \\
\text { Loss, } \%\end{array}$ & 22 & 29 & 15 & 20 & 24 & 16 \\
\hline
\end{tabular}

Calculated nitrite-to-nitrate conversion percentages for all six runs were lower than recent testing with other simulants (generally in the range of $15-20 \%$ conversion), but variations in calculated conversions of $\pm 10 \%$ are not unreasonable based on error propagation considerations. Formate losses were about what was expected prior to the runs. Higher formate losses correlated with lower formate concentrations in Table 12 and Table 14.

A larger formate loss was expected for the ARP/MCU runs compared to the $130 \%$ runs without ARP/MCU. It was assumed that some additional formic acid would be evaporated and removed during the sustained dewatering period accompanying MCU addition. This would increase the formate loss relative to the other four runs where condensate was refluxed back to the SRAT. The lower formate loss with the ARP/MCU version of the SRAT suggests conversion of oxalate into formate, thus mitigating some of the expected formate loss. The impact of nitrate in the MCU addition was accounted for in the pre-run acid calculation and redox estimation. The two runs with MCU appear to have about the same nitrite to nitrate conversion as the two $130 \%$ runs without MCU. Therefore, the MCU nitrate did not appear to cause any major difficulties in the estimated redox calculation if it was accounted for in the initial feed streams.

The SME product (melter feed) analytical data for solids, slurry anions, density, and $\mathrm{pH}$ are given in Table 14.

Table 14. SME Product Data

\begin{tabular}{|c|c|c|c|c|c|c|}
\hline & $\begin{array}{c}\text { Baseline } \\
130 \%\end{array}$ & $\begin{array}{c}\text { Baseline } \\
170 \%\end{array}$ & $\begin{array}{c}\text { Baseline }+ \\
\text { ARP/MCU }\end{array}$ & $\begin{array}{c}\mathrm{w} / \mathrm{NaOH} \\
130 \%\end{array}$ & $\begin{array}{c}\mathrm{w} / \mathrm{NaOH} \\
170 \%\end{array}$ & $\begin{array}{c}\mathrm{w} / \mathrm{NaOH}+ \\
\mathrm{ARP} / \mathrm{MCU}\end{array}$ \\
\hline $\mathrm{Wt} \% \mathrm{TS}$ & 46.6 & 45.3 & 45.3 & 46.1 & 45.5 & 44.2 \\
\hline $\mathrm{Wt} \% \mathrm{IS}$ & 38.7 & 37.0 & 36.6 & 37.3 & 37.0 & 34.7 \\
\hline $\mathrm{Wt} \% \mathrm{SS}$ & 7.9 & 8.3 & 8.7 & 8.8 & 8.5 & 9.5 \\
\hline $\mathrm{Wt} \% \mathrm{CS}$ & 39.3 & 37.3 & 37.9 & 38.5 & 36.9 & 36.5 \\
\hline $\mathrm{Density,} \mathrm{g/mL}$ & 1.338 & 1.335 & 1.349 & 1.341 & 1.349 & 1.317 \\
\hline $\mathrm{pH}$ & 6.58 & 5.05 & 5.80 & 6.38 & 4.62 & 5.17 \\
\hline $\mathrm{HCO}_{2}^{-}, \mathrm{mg} / \mathrm{kg}$ & 45,000 & 49,200 & 47,100 & 49,000 & 58,000 & 51,300 \\
\hline $\mathrm{NO}_{3}^{-}, \mathrm{mg} / \mathrm{kg}$ & 13,600 & 17,500 & 15,700 & 15,400 & 18,200 & 16,000 \\
\hline $\mathrm{NO}_{2}^{-}, \mathrm{mg} / \mathrm{kg}$ & $<100$ & $<100$ & $<100$ & $<100$ & $<100$ & $<100$ \\
\hline $\mathrm{SO}_{4}^{2-}, \mathrm{mg} / \mathrm{kg}$ & 1100 & n.a. & 2100 & 1000 & n.a. & 2200 \\
\hline $\mathrm{Cl}^{-}, \mathrm{mg} / \mathrm{kg}$ & $<100$ & $<100$ & $<100$ & $<100$ & $<100$ & $<100$ \\
\hline
\end{tabular}


Calculated losses of nitrate and formate in the SME cycle were generally very small $(<4 \%$, which was well within the error propagation uncertainty of the SME anion balance calculations assuming $\pm 10 \%$ uncertainties on the SRAT and SME product nitrate and formate concentrations).

\subsubsection{Other Data}

The PC data acquisition system continuously acquired $\mathrm{pH}$ probe data during most of the six runs. The four sets of $\mathrm{pH}$ data for the runs at $130 \%$ acid stoichiometry with and without ARP/MCU are given in Figure 16.

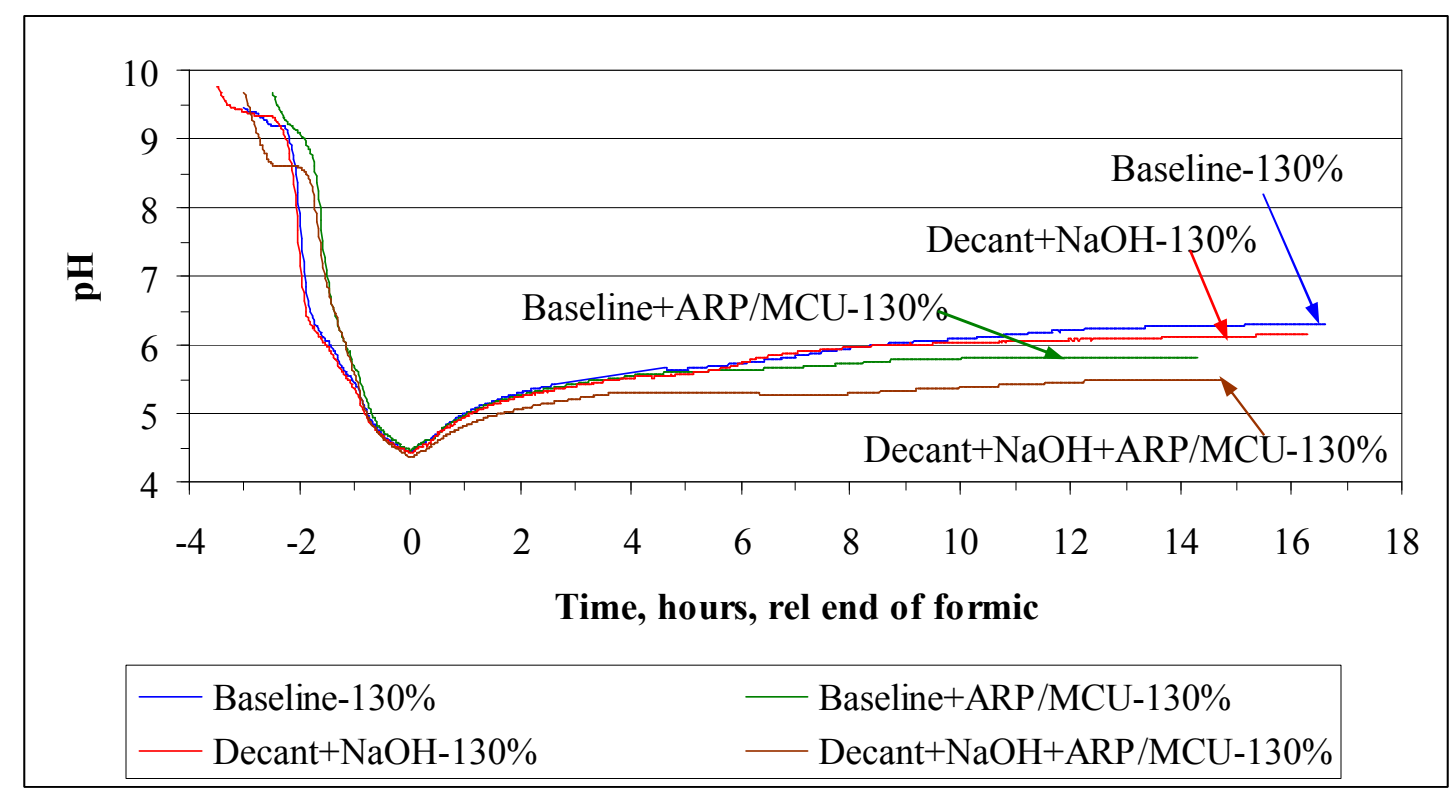

Figure 16. Slurry pH at $130 \%$ stoichiometry

Post-calibration probe data showed up to $0.3 \mathrm{pH}$ unit variations between runs. Nevertheless it appears that the ARP/MCU additions did lead to a lower SRAT product $\mathrm{pH}$ relative to the corresponding runs without the additions. Product sample $\mathrm{pH}$ data confirmed this observation. The baseline decanted simulant and the decanted simulant with added $\mathrm{NaOH}$ had nearly identical $\mathrm{pH}$ profiles without the ARP/MCU addition. Apparently the shift in acid demand from nitrite to hydroxide is also evident for the pair of runs with ARP/MCU relative to the two runs without during the period from -2 to -1 hours before the end of acid addition. It is likely that the ARP has less unquantified acid demand than the SB4 sludge. Data for the two runs at $170 \%$ stoichiometry are given in Figure 17. 
WSRC-STI-2008-00147

Revision 0

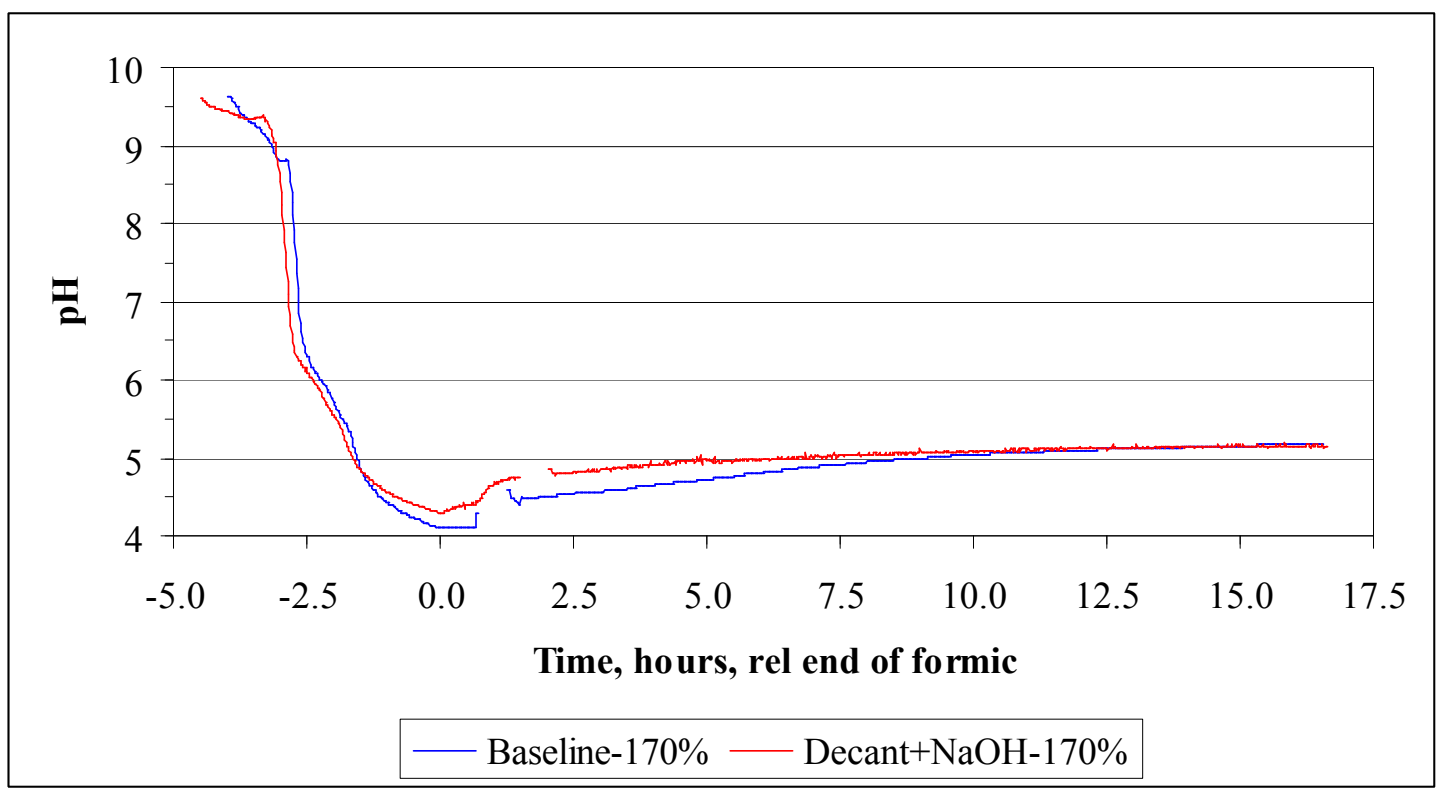

Figure 17. Slurry pH at $170 \%$ stoichiometry

The two traces at $170 \%$ were very close to each other just as the two at $130 \%$ were close. The extra acid demand of the simulant with added caustic did not lead to a significant change in the $\mathrm{pH}$ profile during processing once the extra base was compensated for with additional acid. Sample data, however, indicated a $0.5 \mathrm{pH}$ unit difference between the two $170 \%$ runs, Table 14 .

The SRAT and SME cycles were monitored for foaming. The antifoam strategy was to add $200 \mathrm{ppm}$ before nitric acid, $100 \mathrm{ppm}$ before formic acid, $500 \mathrm{ppm}$ before boiling, and $100 \mathrm{ppm}$ in emergencies or at the start of the SME cycle. No antifoam addition was made after eight hours of boiling in the SRAT. Foaming was not an issue in the SRAT and SME cycles. In the two runs with ARP addition and concentration prior to the normal SRAT cycle, a $200 \mathrm{ppm}$ antifoam addition was made initially before the start of boiling and ARP addition. No foaming was observed, and no additional antifoam was added during this phase. 
WSRC-STI-2008-00147

Revision 0

This page intentionally left blank. 


\subsection{CONCLUSIONS AND RECOMMENDATIONS}

The testing completed and summarized in this report indicates that DWPF can continue to process SB4 using a $130 \%$ stoichiometric acid factor. The available window of stoichiometric factors appears to still include the entire range from $130-170 \%$ for the noble metal concentrations tested. Hydrogen was produced in all six SRAT and SME cycles, but the levels were below the DWPF SRAT and SME cycle limits in all cases. Significant hydrogen generation was seen at $170 \%$, but it was still below the DWPF limit. More hydrogen was made in the runs with added caustic than in the corresponding baseline decant tests. This increase was expected, since sodium hydroxide does not require a stoichiometric factor adjustment to neutralize it, so there was more excess acid in these runs than in the baseline runs.

Nitrite was successfully destroyed in all six SRAT cycles. SRNL can support the proposed Tank $40 \mathrm{H}$ decant from the standpoint of the impact on the DWPF SRAT and SME cycles subject to the inherent uncertainties in modeling the ARP noble metal concentrations. The noble metal concentrations in the ARP were set to the same weight percents in the total solids that they were measured at in the SB4 waste, which was considered likely to be bounding on the actual noble metal content of the ARP transfer to DWPF.

It is recommended that DWPF continue to process SB4 using a 130\% stoichiometric acid factor. Modest quantities of caustic can be added to Tank 40 to alter the glass composition with only minor impacts on the CPC. Data indicated lower $\mathrm{pH}$ 's and increased dissolution of certain species in the SRAT product of the simulant with added caustic at a given stoichiometric factor, which is indicative of the presence of more excess acid relative to the baseline case. Batches with ARP/MCU addition can be processed similarly if they match the projected compositions provided for this study in terms of either acid consuming species concentrations or acid content respectively. Assumptions for formate loss and nitrite to nitrate conversion in the SRAT can be left at current DWPF levels. 
WSRC-STI-2008-00147

Revision 0

This page intentionally left blank. 


\subsection{REFERENCES}

${ }^{1}$ Stone, M.E., F.C. Raszewski, B.R. Pickenheim, T.B. Edwards, D.K. Peeler. Impacts of a Tank 40 Supernate Decant to DWPF Glass Formulation and CPC Processing: A Preliminary Assessment for SB4, SRNL-PSE-2007-00257, Savannah River National Laboratory, Aiken, SC, 29808 (November 2007).

${ }^{2}$ Davis, B.A., SB 4 Flowsheet and Variability Studies for Tank 40 100,000 Gallon Decant, Technical Task Request, HLW-DWPF-TTR-2008-0009, Washington Savannah River Company, Aiken, South Carolina, 29808.

${ }^{3}$ Stone, M. E., SB4 Flowsheet and Variability Study for Tank 40 100,000 Gallon Decant, WSRC-STI2007-00700, Savannah River National Laboratory, Aiken, SC, 29808 (December 14, 2007).

${ }^{4}$ Lambert, D. P., M. F. Williams, S. L. Crump, R. E. Eibling, T. L. White, and D. R. Best, DWPF Flowsheet Studies with Simulants to Determine MCU Solvent Build-up in Continuous Runs, WSRC-TR2006-00154, SRNL, Aiken, SC, 29808 (May 2006).

${ }^{5}$ Koopman, D. C., Preparation, Characterization, and Preliminary SRAT/SME Testing of a Simulant for the Hydrogen and Rheology Modifiers Program, SRNL-PSE-2007-00191, SRNL, Aiken, SC, 29808 (September 2007).

${ }^{6}$ Subosits, S. G., X-CLC-S-00113, Actinide Removal Process Material Balance Calculation with Low Curie Salt Feed, Appendix J, 10/4/04.

${ }^{7}$ Bannochie, C. J., Tank 40 Final SB4 Chemical Characterization Results, WSRC-STI-2007-00674, SRNL, Aiken, SC, 29808 (January 2008).

${ }^{8}$ Stone, M. E. and D. R. Best, Sludge Batch 4 Simulant Flowsheet Studies: Phase II Results, WSRC-STI2006-00109, SRNL, Aiken, SC, 29808 (December 2006). 


\subsection{ACKNOWLEDGEMENTS}

The author wishes to acknowledge the contributions of a number of people. One key element of this report was the sample and process data. The efforts of J. W. DuVall, V. J. Williams, I. A. Reamer, R. J. (Phyllis) Workman, T. O. Burckhalter, and D. M. Marsh are especially appreciated in this regard. V. J. Williams and D. M. Marsh performed the majority of the rheology and slurry density measurements, while J. W. DuVall performed the base equivalents titrations. Thanks are due to J. M. Pareizs and M. F. Williams who maintained the GCs during the testing and reprocessed the GC data after the runs were over. The help of P. T. Simmons and W. A. Thomas in PSAL was also essential to producing the data needed to write this report. 
WSRC-STI-2008-00147

Revision 0

\section{APPENDIX A. OTHER SAMPLE DATA}


Additional processing data are presented here that were not essential to the discussion in Section 3. SRAT products were analyzed for calcined elementals in addition to slurry anions, $\mathrm{pH}$, and $\mathrm{wt} \%$ solids. Elemental results are presented on an oxide basis in Table 15 to match the sludge basis used in Table 1.

Table 15. SRAT Product Calcined Oxides $\left(w \mathrm{t} \%\right.$ at $\left.1100^{\circ} \mathrm{C}\right)$

\begin{tabular}{|c|c|c|c|c|c|c|}
\hline & $\begin{array}{c}\text { Baseline } \\
130 \% \\
\end{array}$ & $\begin{array}{c}\text { Baseline } \\
170 \% \\
\end{array}$ & $\begin{array}{l}\text { Baseline + } \\
\text { ARP/MCU }\end{array}$ & $\begin{array}{c}\mathrm{w} / \mathrm{NaOH} \\
130 \% \\
\end{array}$ & $\begin{array}{c}\mathrm{w} / \mathrm{NaOH} \\
170 \% \\
\end{array}$ & $\begin{array}{l}\mathrm{w} / \mathrm{NaOH}+ \\
\mathrm{ARP} / \mathrm{MCU}\end{array}$ \\
\hline $\mathrm{Al}_{2} \mathrm{O}_{3}$ & 29.3 & 29.0 & 25.9 & 28.5 & 28.7 & 25.0 \\
\hline $\mathrm{BaO}$ & 0.06 & 0.06 & 0.06 & 0.06 & 0.06 & 0.05 \\
\hline $\mathrm{CaO}$ & 3.5 & 3.4 & 3.0 & 3.2 & 3.3 & 2.9 \\
\hline $\mathrm{Cr}_{2} \mathrm{O}_{3}$ & 0.15 & 0.14 & 0.14 & 0.15 & 0.14 & 0.13 \\
\hline $\mathrm{CuO}$ & 0.05 & 0.02 & 0.03 & 0.05 & 0.02 & 0.02 \\
\hline $\mathrm{Fe}_{2} \mathrm{O}_{3}$ & 32.0 & 31.7 & 28.3 & 30.5 & 31.3 & 27.6 \\
\hline $\mathrm{K}_{2} \mathrm{O}$ & 0.14 & 0.14 & 0.11 & 0.13 & 0.13 & 0.11 \\
\hline $\mathrm{MgO}$ & 3.2 & 3.3 & 2.6 & 2.9 & 3.3 & 2.6 \\
\hline $\mathrm{MnO}_{2}$ & 8.2 & 8.2 & 6.7 & 7.6 & 8.0 & 6.9 \\
\hline $\mathrm{Na}_{2} \mathrm{O}$ & 16.2 & 15.5 & 21.0 & 18.2 & 17.9 & 23.7 \\
\hline $\mathrm{NiO}$ & 1.7 & 1.9 & 1.5 & 1.7 & 1.8 & 1.5 \\
\hline $\mathrm{P}_{2} \mathrm{O}_{5}$ & n.d. & n.d. & n.d. & n.d. & n.d. & n.d. \\
\hline $\mathrm{PbO}$ & n.d. & n.d. & n.d. & n.d. & n.d. & n.d. \\
\hline $\mathrm{SO}_{4}$ & 0.88 & 0.69 & 1.3 & 0.85 & 0.73 & 1.3 \\
\hline $\mathrm{SiO}_{2}$ & 3.2 & 3.3 & 2.8 & 3.1 & 3.2 & 2.7 \\
\hline $\mathrm{TiO}_{2}$ & 0.04 & 0.03 & 4.2 & 0.03 & 0.03 & 1.6 \\
\hline $\mathrm{ZnO}$ & 0.06 & 0.06 & 0.06 & 0.06 & 0.05 & 0.05 \\
\hline $\mathrm{ZrO}_{2}$ & 0.07 & 0.05 & 0.10 & 0.07 & 0.06 & 0.08 \\
\hline
\end{tabular}

n.d. - not detected

The noteworthy difference was in the Ti content of the two SRAT products incorporating ARP/MCU process streams. The expected value for $\mathrm{TiO}_{2}$ was about 5.5\% in the SRAT product. Both measured values were lower than expected, but particularly so in the simulant run with added caustic + ARP/MCU. Identical results were obtained by two different sample preparation methods. The SRAT product slurries were fairly fluid, and some segregation of MST solids may have occurred prior to sampling. $\mathrm{The} \mathrm{Na}_{2} \mathrm{O}$ content was about $2.0-2.7 \%$ higher in products with added $\mathrm{NaOH}$ compared to the equivalent runs without added $\mathrm{NaOH}$, which was slightly less than the $3 \%$ increase that was targeted.

The Ti analytical data are at odds with the observations during processing. The ARP feed for the decant $+\mathrm{NaOH}$ case was apparently higher in insoluble solids and more viscous causing more pumping problems during transfer than the ARP feed for the baseline run. Ultimately, all material prepared for each test was transferred into the SRAT, so no significant quantity of solids was left behind. A higher $\mathrm{TiO}_{2}$ content might have been expected for the test with added caustic and ARP/MCU based on this behavior.

Data were obtained on dissolution of cations into the supernate during SRAT processing. $\mathrm{Mg}$ and $\mathrm{Mn}$ were extensively dissolved (50-100\%) during processing and into the SME cycle. Ca was extensively dissolved $(>80 \%)$ during the four SRAT runs without ARP/MCU, but it was significantly less dissolved in the two SRAT runs with ARP/MCU $(\sim 35 \%)$ presumably due to precipitation of $\mathrm{CaC}_{2} \mathrm{O}_{4}$. About $20 \%$ of the Ni dissolved in the two runs at $170 \%$ stoichiometry while only a few percent dissolved in the other four runs. The observed $\mathrm{Ni}$ dissolution was consistent with the strong $\mathrm{pH}$ dependence of the solubility of 
$\mathrm{Ni}(\mathrm{OH})_{2}$. The extents of $\mathrm{Mn}$ dissolution and nitrite destruction indicate that successful processing could be performed with a somewhat lower stoichiometric factor than $130 \%$, assuming there were no major errors in the inputs to the stoichiometric acid calculation.

SME product slurry samples were taken and analyzed from all six runs. Calcined elemental oxide data are given in Table 16.

Table 16. SME Product Calcined Oxides $\left(\mathrm{wt} \%\right.$ at $\left.1100^{\circ} \mathrm{C}\right)$

\begin{tabular}{|c|c|c|c|c|c|c|}
\hline & $\begin{array}{c}\text { Baseline } \\
130 \%\end{array}$ & $\begin{array}{c}\text { Baseline } \\
170 \%\end{array}$ & $\begin{array}{l}\text { Baseline + } \\
\text { ARP/MCU }\end{array}$ & $\begin{array}{c}\mathrm{w} / \mathrm{NaOH} \\
130 \%\end{array}$ & $\begin{array}{c}\mathrm{w} / \mathrm{NaOH} \\
170 \%\end{array}$ & $\begin{array}{l}\text { w/NaOH+ } \\
\text { ARP/MCU }\end{array}$ \\
\hline $\mathrm{Al}_{2} \mathrm{O}_{3}$ & 10.1 & 9.9 & 8.4 & 9.9 & 9.4 & 8.3 \\
\hline $\mathrm{B}_{2} \mathrm{O}_{5}$ & 9.5 & 9.1 & 9.3 & 9.3 & 9.0 & 9.6 \\
\hline $\mathrm{BaO}$ & 0.02 & 0.03 & 0.02 & 0.02 & 0.02 & 0.02 \\
\hline $\mathrm{CaO}$ & 1.00 & 0.99 & 0.87 & 0.96 & 0.97 & 0.84 \\
\hline $\mathrm{Cr}_{2} \mathrm{O}_{3}$ & 0.06 & 0.06 & 0.04 & 0.06 & 0.06 & 0.04 \\
\hline $\mathrm{CuO}$ & 0.02 & n.d. & 0.02 & 0.02 & n.d. & 0.01 \\
\hline $\mathrm{Fe}_{2} \mathrm{O}_{3}$ & 10.8 & 10.8 & 8.9 & 10.7 & 10.9 & 8.9 \\
\hline $\mathrm{K}_{2} \mathrm{O}$ & 0.05 & 0.07 & 0.05 & 0.06 & 0.07 & 0.05 \\
\hline $\mathrm{Li}_{2} \mathrm{O}$ & 5.2 & 5.1 & 5.2 & 5.2 & 5.1 & 5.4 \\
\hline $\mathrm{MgO}$ & 1.0 & 0.97 & 0.79 & 0.97 & 0.93 & 0.79 \\
\hline $\mathrm{MnO}$ & 2.0 & 2.3 & 1.7 & 2.0 & 2.3 & 1.7 \\
\hline $\mathrm{MnO}_{2}$ & 2.4 & 2.8 & 2.1 & 2.5 & 2.9 & 2.1 \\
\hline $\mathrm{Na}_{2} \mathrm{O}$ & 10.7 & 10.5 & 12.4 & 11.4 & 11.1 & 13.4 \\
\hline $\mathrm{NiO}$ & 0.58 & 0.54 & 0.44 & 0.58 & 0.52 & 0.43 \\
\hline $\mathrm{P}_{2} \mathrm{O}_{5}$ & n.d. & n.d. & n.d. & n.d. & n.d. & n.d. \\
\hline $\mathrm{PbO}$ & n.d. & n.d. & n.d. & n.d. & n.d. & n.d. \\
\hline $\mathrm{SO}_{4}$ & 0.25 & 0.20 & 0.35 & 0.19 & 0.17 & 0.29 \\
\hline $\mathrm{SiO}_{2}$ & 47.3 & 46.6 & 48.0 & 47.2 & 46.8 & 49.0 \\
\hline $\mathrm{TiO}_{2}$ & n.d. & n.d. & 1.3 & n.d. & n.d. & 0.50 \\
\hline $\mathrm{ZnO}$ & n.d. & n.d. & n.d. & n.d. & n.d. & n.d. \\
\hline $\mathrm{ZrO}_{2}$ & 0.03 & n.d. & 0.03 & 0.03 & n.d. & 0.02 \\
\hline
\end{tabular}

n.d. - not detected

The SME elemental data were generally consistent with the SRAT product elemental oxide data, i.e. roughly $34 \%$ as large for sludge species as in the SRAT products. This included about 2.5 times more $\mathrm{TiO}_{2}$ in the baseline simulant SME product with added ARP/MCU compared to the decant with added caustic SME product with ARP/MCU. The expected $\mathrm{SME} \mathrm{TiO}_{2}$ concentration was about $1.8 \%$ in the calcined solids. Apparently the cause of difficulty in the SRAT Ti was still present in the SME. Raw ICP-AES composition data were reported as either $\mathrm{Mn}$ or $\mathrm{MnO}_{2}$, but the likely form in the glass would be $\mathrm{MnO}$, so $\mathrm{MnO}$ values were calculated and are also given in the table. 
WSRC-STI-2008-00147

Revision 0

This page intentionally left blank. 
WSRC-STI-2008-00147

Revision 0

APPENDIX B. RHEOLOGY DATA 
Rheology data for the two untrimmed sludges is given in the two figures below:
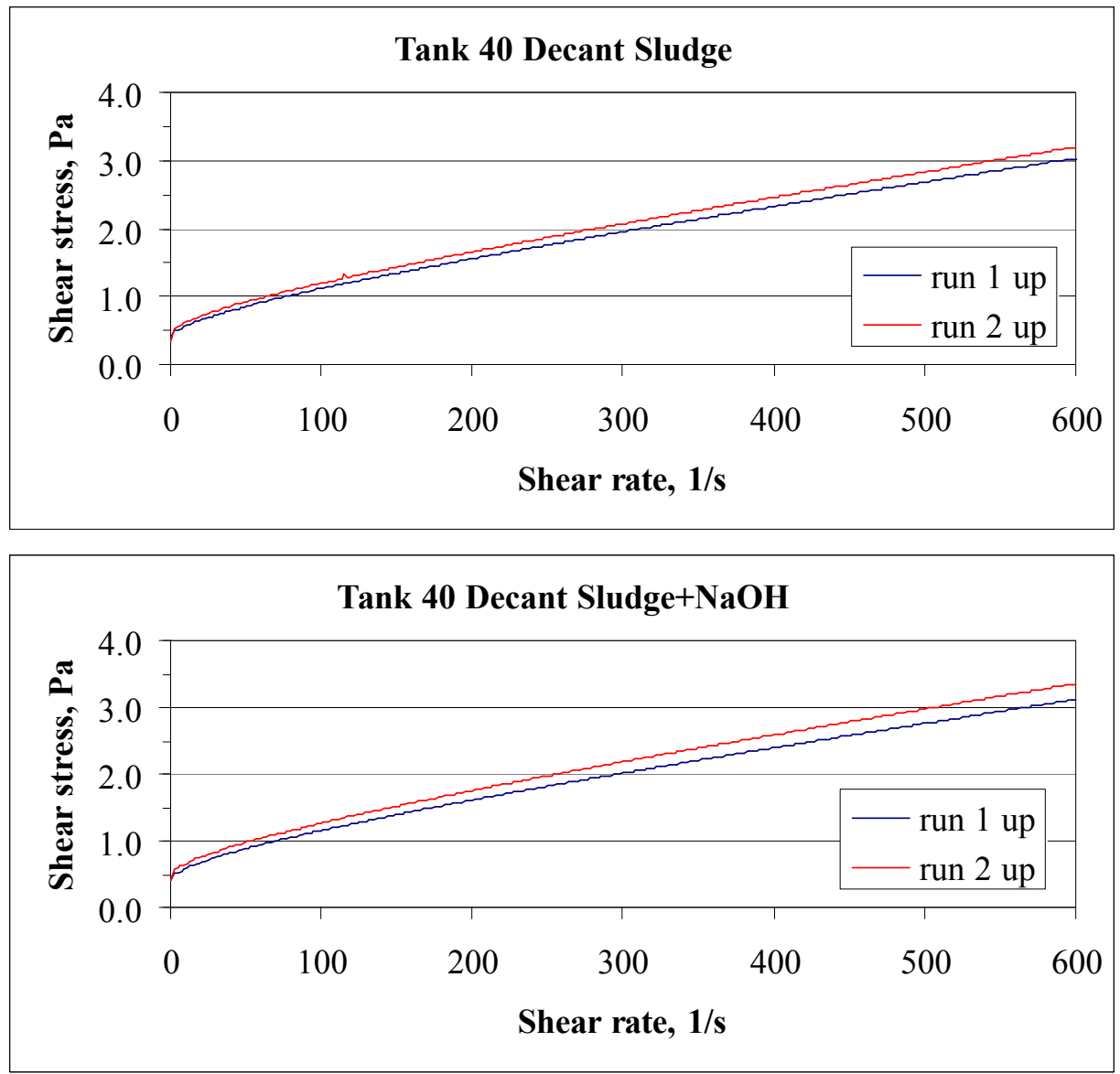

The two sludges were fairly thick and similar in their rheological properties. The flow curves showed excellent reproducibility.

SRAT product rheology data for the six SRAT products are given next. Data were fit from shear rates of $100 / \mathrm{sec}$ to $500 / \mathrm{sec}$ unless there was unusual curvature in the flow curve.

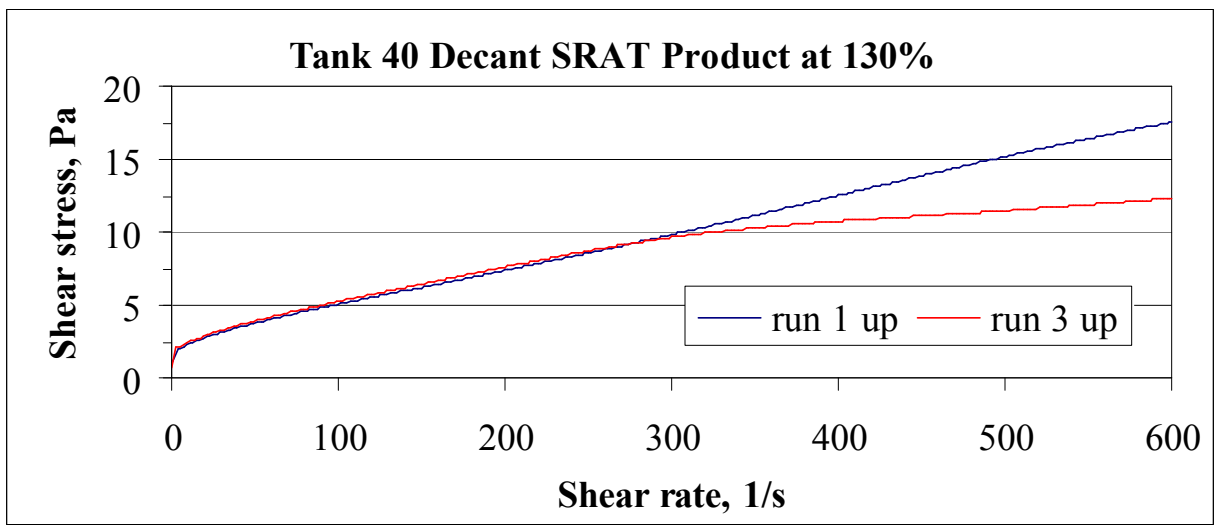


WSRC-STI-2008-00147

Revision 0
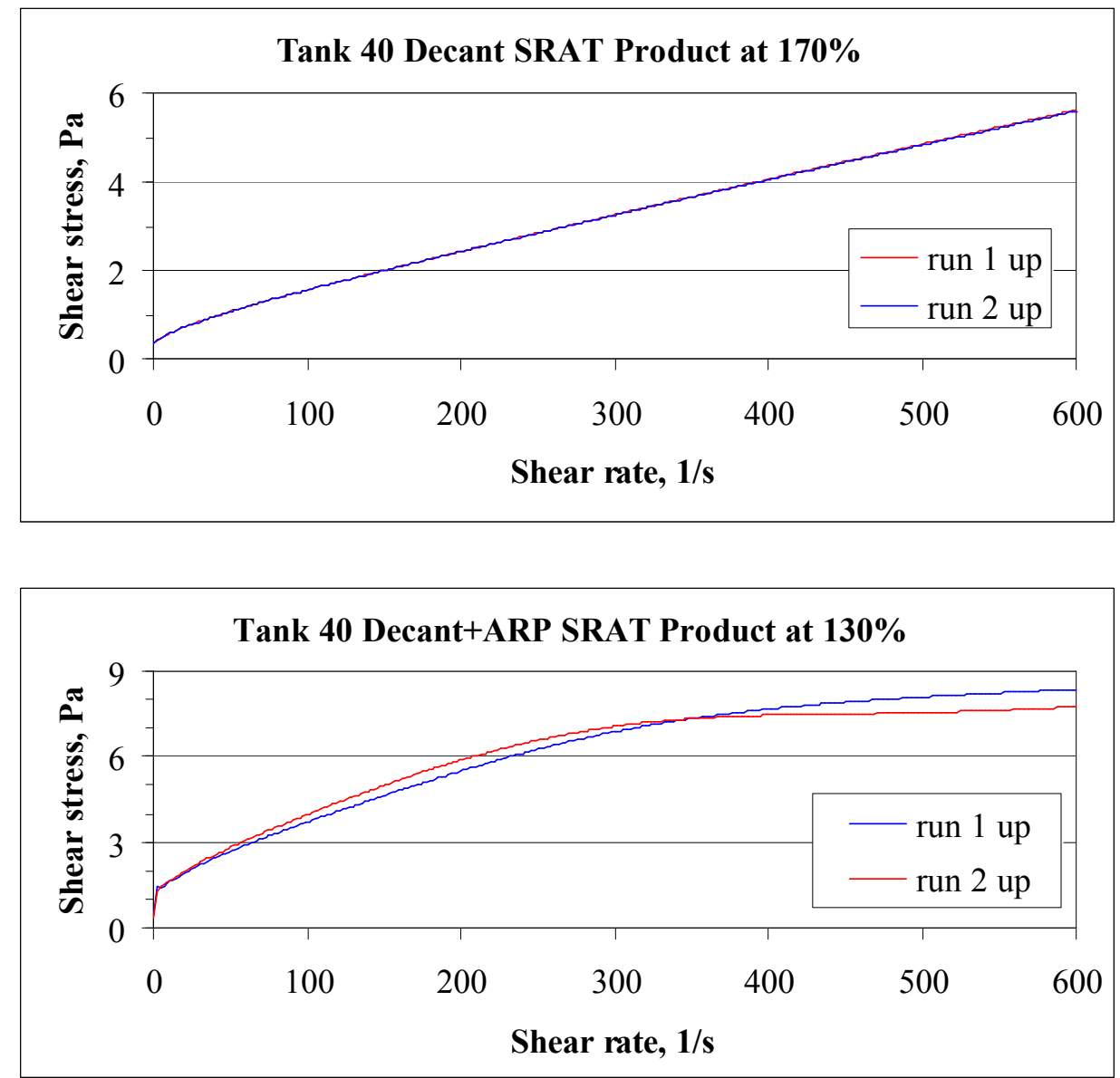

The above sample was fit over a reduced range of shear rates because of the curvature that became pronounced at about a shear rate of $350 / \mathrm{sec}$.

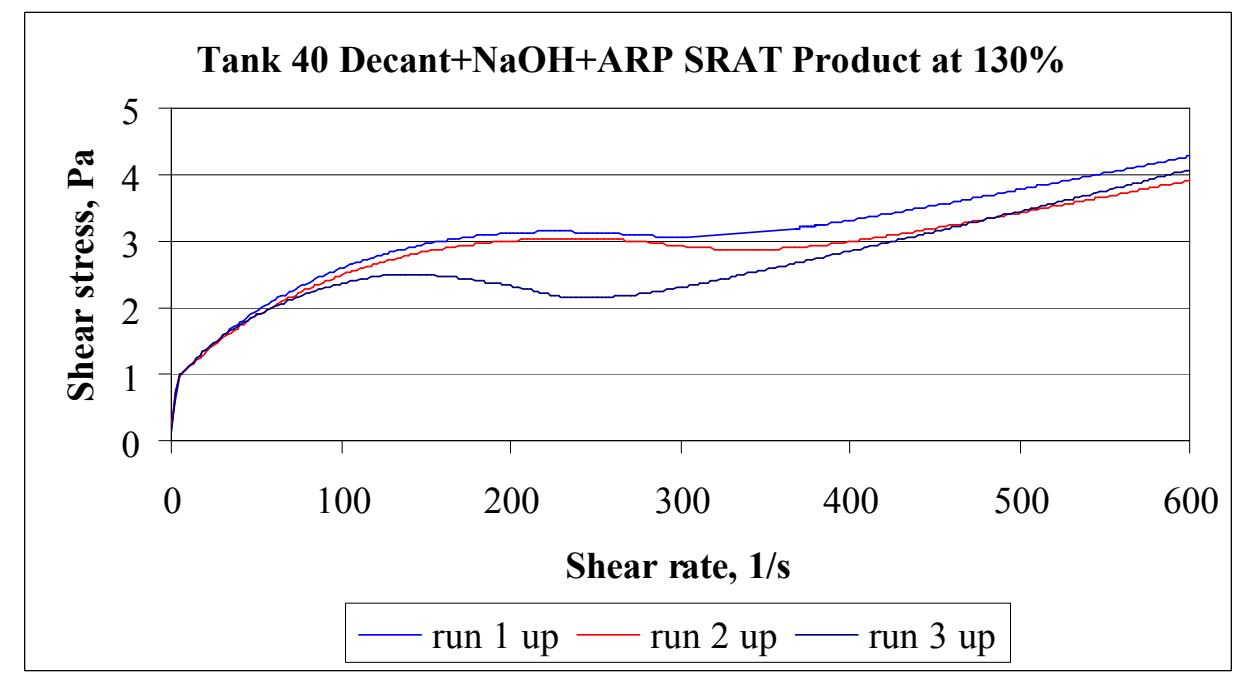

The above sample would not be appropriately described by a Bingham plastic rheological equation fit, but a yield stress was estimated using the low shear rate region and extrapolating to zero shear rate. 
WSRC-STI-2008-00147

Revision 0
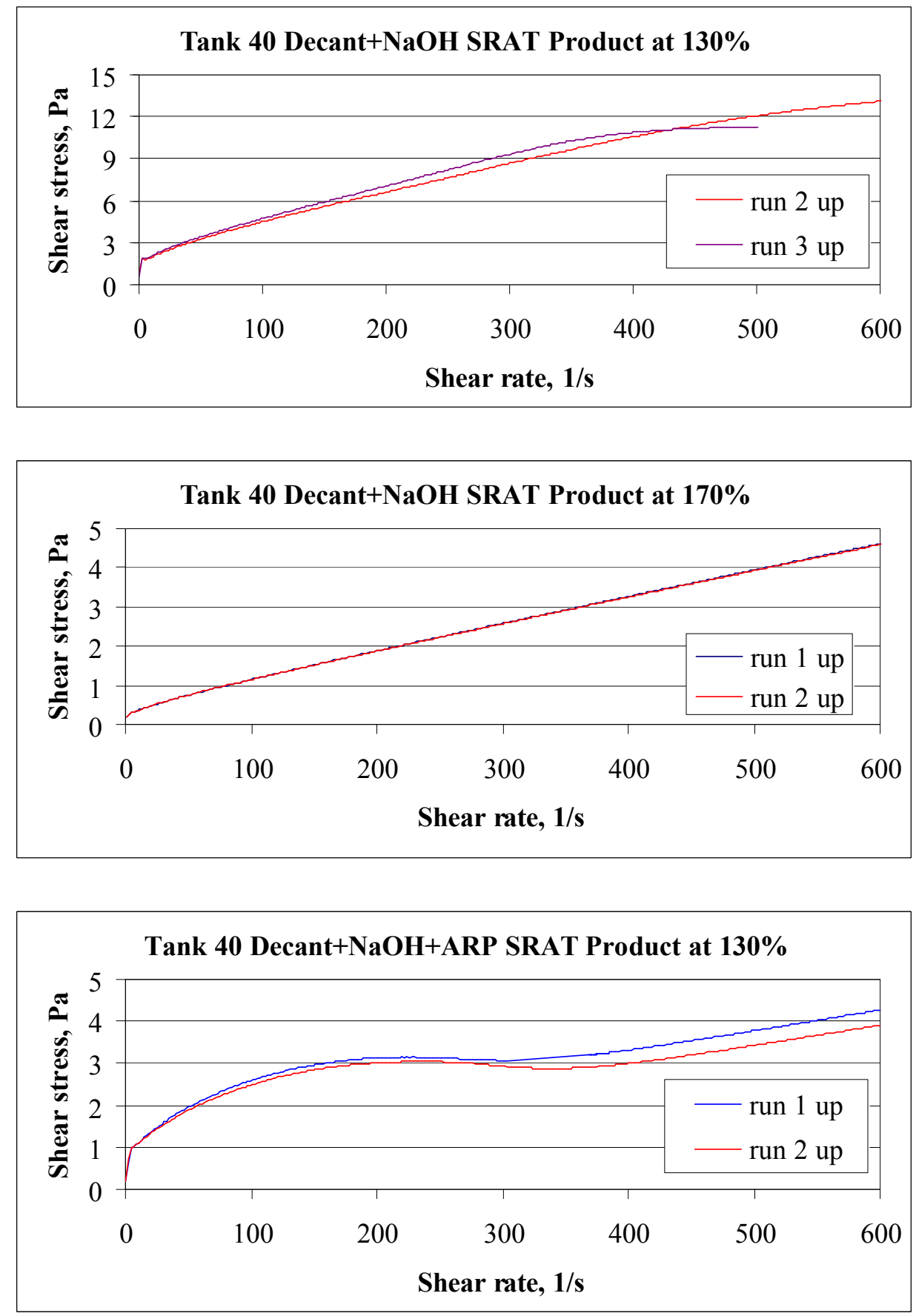

This last SRAT product could not be fit to the Bingham plastic model due to the shape of the flow curve. SME product rheology data are given below for the six SME product slurries. Flow curves were fit from a shear rate of 50/s to higher shear rates in the generally linear region of the flow curve to produce the constants in Table 9. 
WSRC-STI-2008-00147

Revision 0
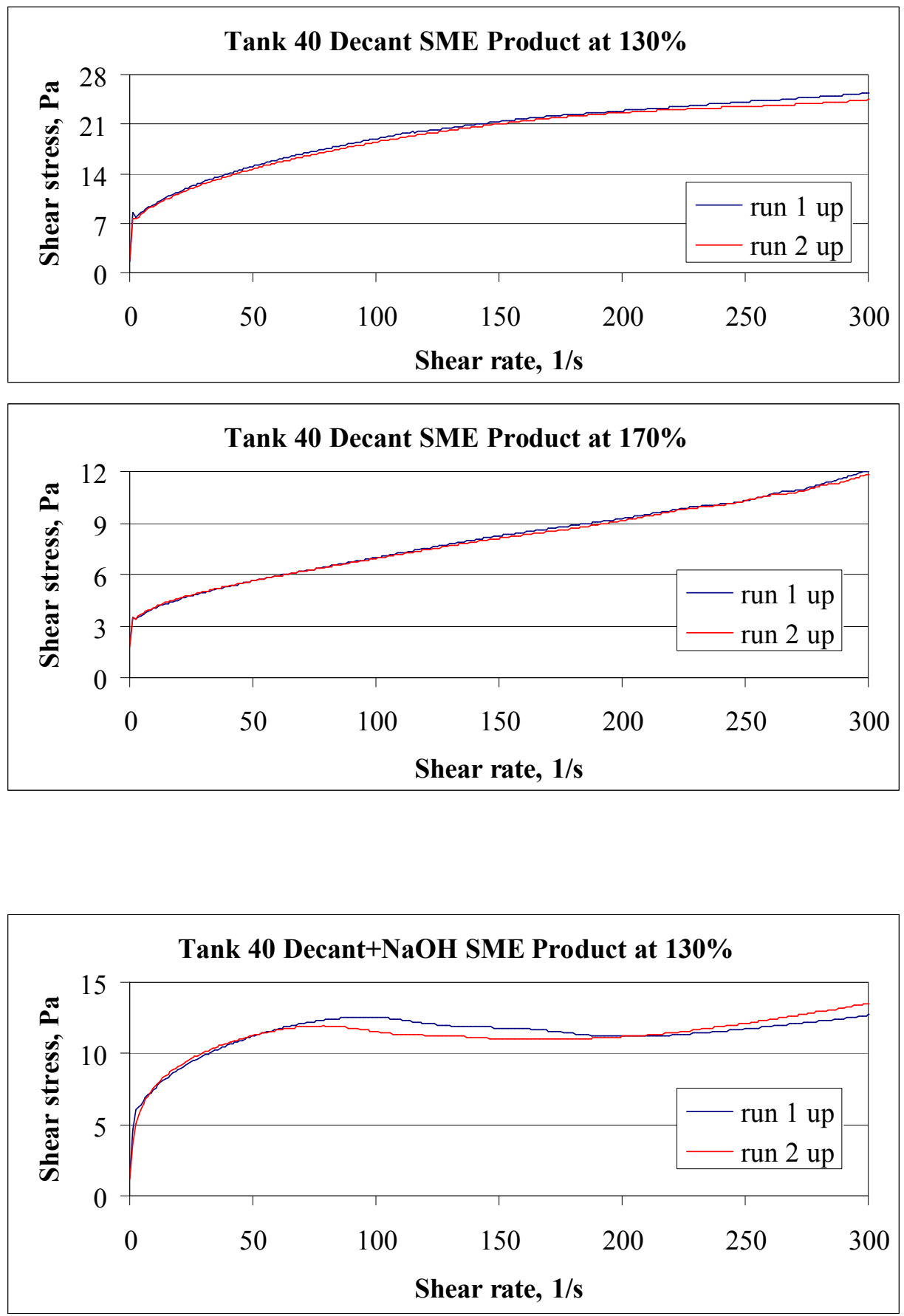

Obviously, the flow curve data for the Tank 40 Decant $+\mathrm{NaOH}$ at 130\% SME product did not follow the pattern of the flow curves for most of the other samples. This shape led to issues with using the Bingham plastic rheological equation to fit the data. 

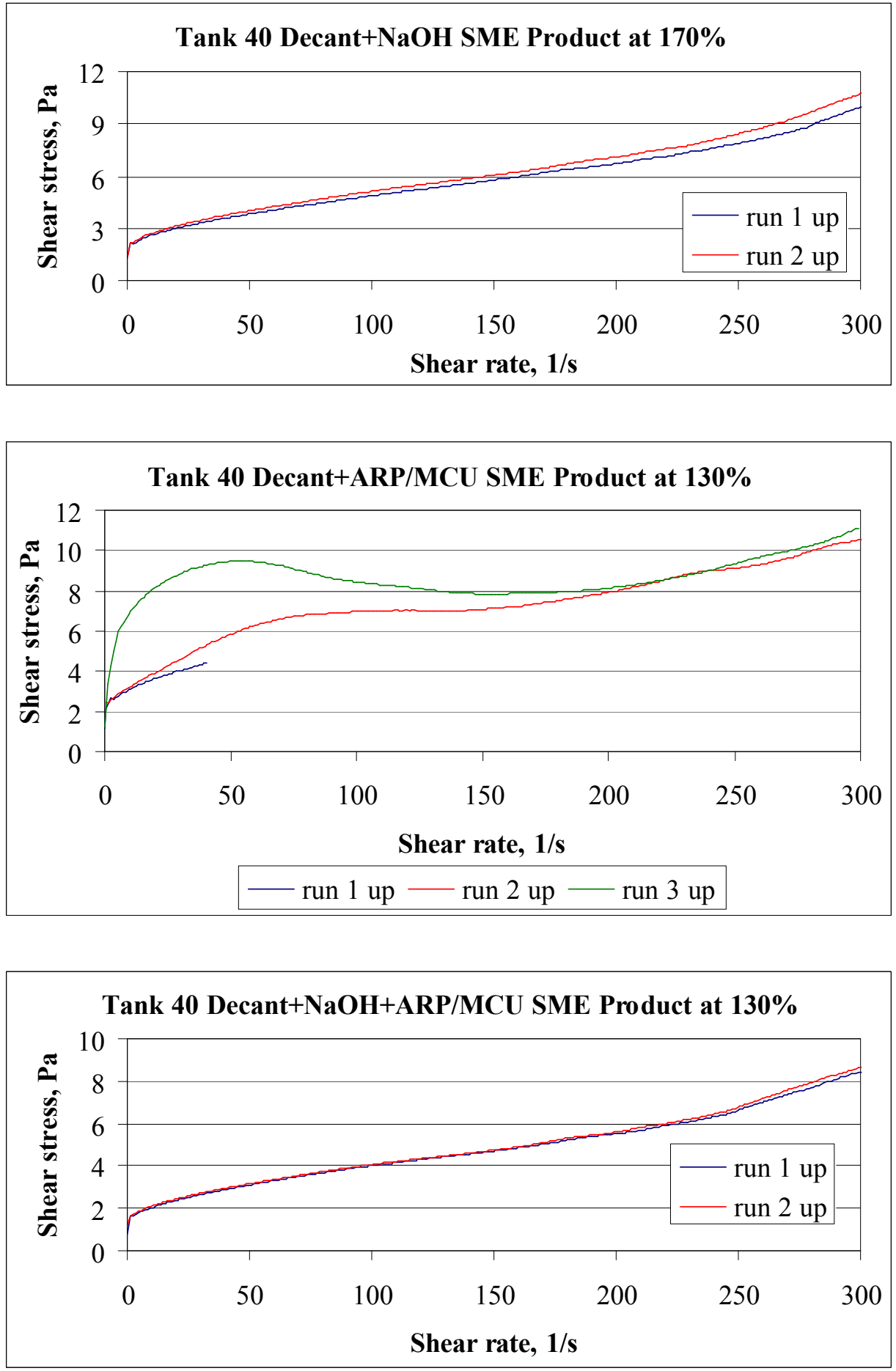

All rheological data were above the curves for the predicted onset of Taylor vortices (secondary flows) for the sludges, SRAT products, and SME products. 


\section{Distribution:}

J. C. Griffin, 773-A

D. A. Crowley, 999-W

C. C. Herman, 773-42A

A. B. Barnes, 999-W

B. J. Giddings, 786-5A

S. D. Fink, 773-A

J. E. Occhipinti, 704-S

J. M. Bricker, 704-27S

J. Stuberfield, 766-H

R. T. McNew, 704-27S

J. F. Iaukea, 704-30S

J. W. Ray, 704-S

B. A. Davis, 704-27S

T. L. Fellinger, 704-26S

H. B. Shah, 766-H

J. M. Gillam, 766-H

B. A. Hamm, 766-H

N. E. Bibler, 773-A

C. J. Bannochie, 773-42A

J. M. Pareizs, 773-A

D. P. Lambert, 773-A

S. H. Reboul, 773-42A

D. K. Peeler, 999-W

M. E. Smith, 999-W

M. E. Stone, 999-W

B. R. Pickenheim, 999-W 